\title{
Effects of deforestation and weather on diurnal frost heave processes on the steep mountain slopes in south central Japan
}

\author{
Kenichi UENO ${ }^{1 *}$, Kousei KUROBE ${ }^{2}$, Fumitoshi IMAIZUMI ${ }^{3}$, Ryoko NISHII $^{4}$
}

${ }^{1}$ Life and Environmental Sciences, University of Tsukuba, Tsukuba, Ibaraki JAPAN

2 Pacific Consultants Co., Ltd., Tokyo JAPAN

${ }^{3}$ Faculty of Agriculture, Shizuoka University, Shizuoka JAPAN

${ }_{4}^{4}$ Public Works Research Institute, Tsukuba, Ibaraki JAPAN

*Corresponding author: ueno.kenichi.fw@u.tsukuba.ac.jp

(Earth Surface Processes and Landforms、Accepted 18 June 2015: DOI: 10.1002/esp.3776)

ABSTRACT: Freezing and thawing processes play an important rule for the gravitational transport of surface materials on steep mountain slopes in Japan. The effects of deforestation on frost heave activity were observed through the 2012/13 winter season in Ikawa University Forest, a southern mountainous area in central Japan (1180-1310 m above sea level). During periods without snow cover, needle ice development prevailed at a clear-cut site, and the downslope sediment movement of upper soil was $10-15 \mathrm{~cm}$ through the winter season. At a non-cut site, rise and fall in the ground surface level prevailed on a weekly scale, with no evident downslope movements at the surface; ice lens formation in the soil layer is assumed. Abrupt changes in the radiation budget, such as the strengthening of nighttime radiative cooling and increases in daytime direct insolation, induced frequent development/deformation of needle ice at the clear-cut site. In snow-free periods, the day-today variability in needle ice growth length and in nighttime averaged net radiation showed significant correlations; cloudy weather with warmer and moist air intrusion associated with synoptic disturbances prevented the occurrence of needle ice. Namely, day-to-day weather changes directly affected the mass movement of the upper soil after deforestation. Shallow snow cover occurred discontinuously through the winter and is likely an important factor in keeping the soil moisture sufficiently high in the upper soil layer for initiating needle ice 
during snow-free periods. We also discuss contributions of coastal extratropical cyclone activities providing both snow cover and cloudy weather in the southern mountain areas of central Japan to the intra-seasonal variability in frost heave and its indirect effect on soil creep and landslides on the deforested steep slopes.

KEYWORDS: diurnal frost heave, deforestation, micro-meteorology, snow cover, central Japan

\section{Introduction}

Freezing and thawing processes contribute strongly to the activation of surface soil layers on steep slopes (Matsuoka, 2001; Imaizumi et al., 2006). They play an important role in the development of periglacial landscapes as they constantly cause gravitational mass movement, such as dry ravel, the gravitational transport of surface materials by rolling, sliding, and bouncing across the surface (Gabet and Dunne, 2002; Imaizumi et al., 2015), and soil creep that sometimes accounts for more than $40 \%$ of the sediment transport rate on hillslopes. Freezing and thawing processes activate soil surface erosion (Roberts and Church, 1986; Benda, 1990; Kværnø and Øygarden, 2006). Since soil creep and dry ravel are considered important infilling processes for landslide scars and debris-flow torrents, a clear understanding of freezing and thawing processes is required to achieve better sediment disaster mitigation (Benda, 1990; Sasaki et al., 2000).

Most studies of frost heaving have been conducted in high latitudes in permafrost areas (after Williams and Smith, 1989) causing diurnal to seasonal-scale deformation of land surface (Smith, 1988; Matsuoka, 1998a). Segregation ice, such as needle ice and ice lenses, results from heaving in the upper soil layers (e.g., Higashi and Corte, 1971; Anderson, 2002). Needle ice forms on the soil surface below $0^{\circ} \mathrm{C}$ and is characterized by diurnal development 
stages. The necessary conditions include: 1) sufficient radiative/evaporative cooling; 2) sufficient soil moisture; and 3) stable water flux by capillary force (after Outcalt, 1971). Ice lenses are generally oriented normal to transient freezing, with a banded structure that changes depending on the soil type/structure, applied load, and freezing conditions (Konrad and Duquennoi, 1993). Environmental controls, such as ground cover (i.e., snow cover and vegetation) and weather (i.e., diurnal temperature variation, precipitation, surface radiation balance), limit the frequency of effective frost days considerably (Boelhouwers, 1998; Boelhouwers et al., 2003; Haussmann et al., 2009). Nel et al. (2009) noted that synoptic-scale weather systems strongly affect the duration and intensity of soil frost processes on Marion Island in the southern Indian Ocean, where a maritime climate dominates. In Japan, Konko (1982) identified the basic conditions for needle ice development, such as a surface temperature below $0^{\circ} \mathrm{C}$ without snow cover, a fine-grained soil texture, and a subsurface water supply. In addition, a negative correlation was identified between the length of needle ice and the nocturnal cloud amount, and a heat budget equation was proposed to relate the amount of needle ice development with the longwave radiation budget minus thermal conductivity. Seto et al. (2010) found through an indoor experiment that the existence of snow cover affects mass movement by changing the surface soil moisture condition. To summarize, frost heave processes in the upper soil layer are quite sensitive to micro meteorological and hydrological processes without snow cover in Japan during the variable weather of the winter season.

In accordance with frost heaving, upper soils move as needle ice creep and frost creep (Sawaguchi, 1987; Matsuoka, 2001). For example, a sediment supply is generated by the diurnal frost heave of loamy sediment in a maritime subarctic island (Boelhouwers et al., 2000). Surface soil is displaced perpendicular to the frost heaving layer as needle ice and ice lenses develop. Soil then moves downslope by the force of gravity, affected by multiple factors such as the tension of roots and slope gradient (Higashi and Corte, 1971; Matsuoka, 1998b). 
Branson et al. (1996) revealed sediment inclusion processes during needle ice growth through laboratory experiments. The depth of the movement layer differs depending on the freezing process (Matsuoka, 1998b). As the surface flow and seepage flow from an upper slope during rainfall with high rain intensity are direct factors in causing a landslide, the freezing and thawing process is an indirect factor in activating soil surface erosion (Kværnø and Øygarden, 2006). Uchida et al. (1992) revealed that the depth of the melting layer differed largely between south- and north-facing slopes in Nagano Prefecture in central Japan, and attempted to estimate the site dependency of the start day of upper soil ice melting as a function of insolation amount and duration.

Vegetation cover reduces the amount of surface erosion by suppressing surface flow as well as by protecting the surface soil from raindrop splash (Roberts and Church, 1986; Edeso et al., 1999). Ueno et al. (2010) also revealed that degradation of the soil surface is controlled by the existence of vegetation and its growth condition on outdoor experimental slopes in Japan. Forest vegetation is one of the important factors controlling hydrogeomorphic processes in mountainous areas. The growth of roots by afforestation is well known to stabilize top soil and contribute to reducing shallow landslides (Guthrie, 2002; Brardinoni and Church, 2004; Imaizumi et al., 2008). Ko (1976) reported that the sediment transport rate associated with the freeze-thaw process in a bare area in Japan was much higher than that in an adjacent forested area. To mitigate sediment disasters (landslides and debris flows) that occur during severe Asian storms, such as typhoons, the Baiyu-Meiyu front, or the heavy snow associated with a winter monsoon, revegetation on bare slopes has been actively performed. However, most of the studies revealing the relationship between the freeze-thaw process and subsurface movements are limited to above timberline or non-vegetated areas (Benedict, 1970; Matsuoka, 1998a; Vieira et al., 2003), and observational studies in relation to deforestation are rare in Asia. In particular, the micrometeorological factors that affect differences in the freeze-thaw activity between bare and forested areas have not been 
clarified.

More than $70 \%$ of the mountainous areas in central Japan are covered by forest. About $40 \%$ of the forests are planted, composed of coniferous trees such as Japanese cedar, cypress, and larch. In the winter season, a winter monsoon from Siberia provides clear weather contrasts, yielding heavy snow in the western coastal regions along the Sea of Japan and sunny, dry conditions on the southeastern Pacific side. At the same time, moving extratropical cyclones provide sporadic precipitation and cause occasional seasonal snow cover in high-elevation areas. Therefore, plausibly, freezing and thawing of the ground will prevail in the eastern and southern coastal mountains, which do not have long-term seasonal snow cover. This occurs due to nocturnal radiative cooling and daytime thawing under sufficient insolation, where a certain amount of soil wetness is expected to be provided from the intra-seasonal extratropical cyclone activity. However, few studies have simultaneously monitored the occurrence of frost heave and weather variability through a winter season.

The central mountains on the Pacific side of Japan are composed of steep slopes due to plate movement. Process studies on landslides and soil creep have been conducted in the Ikawa University Forests, University of Tsukuba, located at the northern edge of Shizuoka Prefecture (e.g., Imaizumi et al., 2010). In 2012, deforestation by clear-cut logging was performed in part of the artificial forest of the Ikawa Forests at $1200 \mathrm{~m}$ above sea level (ASL). To reveal the hydrometeorological conditions for the freeze-thaw processes affecting the mass movement of upper soil layers in forested mountains, intensive micrometeorological and subsurface hydrological observations were conducted both in forested and deforested areas throughout a winter season. Based on the observation data, we assessed the factors affecting the timing and duration of freeze-thaw processes in areas with and without forest. Then we examined the functions of the intra-seasonal variability in weather conditions associated with coastal cyclone activities that control the occurrence and development of needle ice in areas of clear-cut logging. Also, the relationship between the extent of needle ice development 
and its associated downward sediment transportation was documented.

\section{Observation sites and design}

Ikawa University Forest, managed by the University of Tsukuba, is located on the southern side of the Akashi mountain range in central Japan (Fig. 1, left). The University Forest has an area of 1700 ha extending 950-2400 m ASL and is composed of steep slopes with gradients of $38-40^{\circ}$. Below $1600 \mathrm{~m}$ ASL, the forest consists of Mongolian oak, beech, Japanese cedar, Japanese cypress, and maple, whereas above this elevation, it comprises Tsuga diversifolia, Veitch's silver fir, and larch. The geological strata are composed of alternating sandstone and shale layers covered by brown forest soil and podzol. Frequent sediment movements in the area have occurred during nonprecipitation periods in winter and spring (Imaizumi and Ueji, 2012).

The target experiment area was 1.5 ha and faced west at 1180-1310 m ASL (Fig. 1, right). In the University Forest, that area is composed of 38-year-old Japanese cypress (evergreen needle leaf) trees. A 0.87-ha area in the upper part of the experiment area was clear-cut during March-September 2012. Logging was conducted by skyline yarding to avoid dragging logs and damaging the slope surfaces. After clear-cutting, branches and leaves of harvested trees were left on the ground to protect the slopes from surface erosion. These harvesting operations conducted in the Ikawa University Forest are common in Japanese forestry. After clear-cutting, Japanese cypress trees were replanted in the area in spring 2013.

Preliminary observations of the micrometeorology in the experiment area were carried out from November 2011 to March 2012, before clear-cutting, and intensive hydrometeorological observations were performed during winter (November 2012-March 2013) on the upper clear-cut (CC) site $\left(35^{\circ} 20^{\prime} 58.9^{\prime \prime} \mathrm{N}, 138^{\circ} 13^{\prime} 49.2^{\prime \prime} \mathrm{E}\right)$ and lower non-cut (NC) site $\left(35^{\circ} 20^{\prime} 56.1^{\prime \prime} \mathrm{N}\right.$, $\left.138^{\circ} 13^{\prime} 46.6^{\prime \prime} \mathrm{E}\right)$. Both sites were located on a west-facing slope; the slope gradient at the CC 
site $\left(35-45^{\circ}\right)$ was slightly greater than that at the NC site $\left(30-40^{\circ}\right)$. Small-scale concaveconvex topography exists at each site. We set up three monitoring plots corresponding to the small-scale topography at the CC site (CCR, CCS, and CCV at convex, planar, and concave slopes, respectively) and two monitoring plots at the $\mathrm{NC}$ site (COR and COS on convex and concave slopes, respectively; Fig. 1, right). Figure 2 shows views of the plots with the instrument settings. The locations of the observational parameters, with sensor heights from the ground, are listed in Table 1.

For the micrometeorological observations, air temperature $(\mathrm{Ta})$ and relative humidity were monitored using thermo-hygrographs (Onset Co. HOBO U23). The observation interval for air temperature and relative humidity was set at 10 minutes. Rainfall at both sites (CC and CO) was observed using tipping bucket rain gauges ( $0.2 \mathrm{~mm}$ for one tip) without a heating system. A micro-wind speed anemometer from Makino Co. was also set to monitor the local circulation at the center of the clear-cut site (data were missing after Feb. 2013). To evaluate the precise radiation budget at the surface, four radiation components were measured with a CNR 4 Net Radiometer (Kipp \& Zonen Co.) at the CCS and COS sites. The target ground was covered by heterogeneous materials (leaves and branches of harvested trees, grasses, soil, and snow cover) and had a rugged ground surface terrain. Accordingly, although the ground surface temperature (Ts) is a key parameter to control the heat and radiation budget, a temperature sensor cannot measure a representative Ts condition around the plot. Therefore, the Ts was estimated from upward longwave radiation (Lup) as Lup $=\sigma \varepsilon \operatorname{Ts}^{4}$, according to the Stefan-Boltzmann law, where $\sigma$ is the Stefan-Boltzmann constant and $\varepsilon$ is emissivity. The emissivity varied from 0.88 to 0.99 according to the composition of the natural ground; however, it was set at a constant value of 1.0 in this study. The Ts value represents an aerial averaged estimate for a footprint within $\sim 45^{\circ}$ looking down from the 2 -m sensor level. Soil moisture was observed with Amplitude Domain Reflectivity soil moisture sensors (Delta-T Co. SM300) having an accuracy of $2.5 \%$ at an interval of 10 minutes at $5 \mathrm{~cm}$ depth from the 
ground surface.

Long-term meteorological data were archived from two automatic weather stations (AWSs). One AWS (IKW-AWS) was located at $1175 \mathrm{~m} \mathrm{ASL,} 2 \mathrm{~km}$ south of the experiment area, and the other was an Automatic Meteorological Acquisition System (AMeDAS) located $17 \mathrm{~km}$ downstream (south) at 755 m ASL operated by the Japan Meteorological Agency (JMA). The AMeDAS was equipped with a ventilated temperature sensor and a rain gauge with a heating system. The IKW-AWS was equipped with a non-ventilated temperature/humidity sensor and rain gauge without a heating system. The general winter weather on the Pacific side of the main island of Japan (Honshu), where the Ikawa area is located, is mostly fair with dry conditions because winter monsoon is blocked by the central mountain ranges in the northwest (Suzuki, 1962). Average winter meteorological records during 1981-2010, from the Ikawa AMeDAS, indicate $5.7 \mathrm{~h} /$ day for daily sunshine duration, $327 \mathrm{~mm}$ for total precipitation, and $0.7 \mathrm{~m} / \mathrm{s}$ for wind speed. The daily average minimum and maximum air temperatures at IKW-AWS during the winters from 1993 to 2002 were $-2.0^{\circ} \mathrm{C}$ and $+7.3^{\circ} \mathrm{C}$, respectively, indicating that the Ta often crosses at the $0^{\circ} \mathrm{C}$ level at the experiment site. According to the JMA weather report, the winter weather in the Tokai area, where the Ikawa University Forest is located, was normal in insolation duration and temperature with a $10 \%$ increase in precipitation during the 2012/13 winter. Synoptic-scale disturbances providing winter precipitation in the Pacific coastal areas include extratropical cyclones and associated cold fronts. During the observation period, two-thirds of the snowfall days in the experimental site were due to coastal cyclones and the other one-third was due to passing cold fronts (details are included in the Results section).

The occurrence of freezing and thawing was detected by extensometers and digital interval cameras set at CCR and COR. The extensometers were produced by Kyo-WA Co. (DT-100A) and had a $0-100 \mathrm{~mm}$ range with $0.5 \%$ accuracy. The observation interval was 1 hour, and the output voltage in the $0-1.5 \mathrm{mV}$ range was converted to displacement (along a direction at 
right angles to the ground surface, with units of $\mathrm{mm}$ ) using a calibration formula for each sensor based on laboratory experiments. The gauge produced diurnal biases in the nonfreezing seasons, such as in March. Bias correction was performed using the Ts estimated from upward longwave radiation data. The main body of each extensometer was fixed to a metal beam located $\sim 40 \mathrm{~cm}$ above the ground surface (Fig. 2). The edges of the beam were supported by metal perpendicular posts whose foundations penetrated down to a depth free from freezing even in the coldest season $(>40 \mathrm{~cm})$. Therefore, the level of the main body of the extensometer was unaffected by freeze-thaw activities. The edge of the detection part extending from the bottom of the main body was attached to the ground surface and moved with changes in the ground surface level.

Digital interval cameras (Brinno GardenWatchCam) were set at $20 \mathrm{~cm}$ above the ground at CCR and COR, and the daytime soil surface rise and fall around the extensometers were monitored at 10-minute intervals. The occurrence of snow cover was also captured by the cameras. By comparing the location of at least three pebbles on the ground surface in images, daily displacement of the ground surface sediment in the slope direction. Comparison of the frost heave value observed by the extensometers with that obtained from analysis of camera images showed that the timing of changes from the two methods corresponded well. However, the observed values by the extensometers were generally lower than those from the camera images. In areas of loose ground surface, the head of the heaving gauges penetrated shallowly into the ground, possibly resulting in the lower observation values from the extensometers. The interval cameras, however, could not monitor frost heave before sunrise due to darkness. Therefore, we converted the relative displacement values recorded by the extensometers to actual displacement by applying the calculated relationship between the displacement recorded by the extensometers and that from the camera images.

Particle size affects freeze-thaw activity (e.g., Meentemeyer and Zippin, 1981; Harris et al., 1993). Figure 3 shows the particle-size distributions in the surface soil at five plots. The 
distribution is almost the same, except that particles at CCV were coarser than in other plots due to the accumulation of boulders transported as rockfall and dry ravel from the upper slopes. The difference in grain size between the CC and NC sites was less clear than that between plots within the same site.

\section{Results of field measurements}

Changes in micrometeorological conditions due to deforestation

Clear-cutting changes the thermal and hydrological conditions of the ground surface, which strongly affects freezing and thawing processes in the soil. To visualize the conditions with and without forest, sky-view images taken with a fisheye lens at CCS and COS points were compared (see Fig. 4). Clear-cutting obviously caused much more direct insolation at the ground surface compared to that at the NC site. Due to the steep slope forming a valley, the fraction of sky visible at CCS in the CC site (Fig. 4a) was smaller than that in the nonmountainous areas with lower elevations, and caused a shorter and limited duration of daytime direct insolation at the surface. However, the morning direct insolation was enough to warm the surface as explained later because of high elevated slopes, not at the bottom of the valley. At the NC site (Fig. 4b), the fraction of sky visible was significantly diminished, as insolation was interrupted by a mature crown canopy (cypress or evergreen trees) in the daytime and by trunks in the morning and evening.

The diurnal variations in Ta observed at $2 \mathrm{~m}$ height and the Ts estimated from upward longwave radiation were averaged over the analysis period (December 2012-March 2013) and compared between the $\mathrm{CC}$ and $\mathrm{NC}$ sites (Fig. 5). The daily averaged Ta was $0.6^{\circ} \mathrm{C}$ at the $\mathrm{CC}$ site and $0.5^{\circ} \mathrm{C}$ at the $\mathrm{NC}$ site, a small difference. The Ta at the $\mathrm{CC}$ site was $1.4^{\circ} \mathrm{C}$ warmer at $\sim 14: 00$ hours and $0.5^{\circ} \mathrm{C}$ colder before sunrise than at the $\mathrm{NC}$ site. However, the Ts showed 
large diurnal differences between the $\mathrm{CC}$ and $\mathrm{NC}$ sites, such that the daytime maximum $\mathrm{Ts}$ was $\sim 11.5^{\circ} \mathrm{C}$ warmer and the nighttime minimum Ts was $\sim-1.4^{\circ} \mathrm{C}$ colder at the $\mathrm{CC}$ site. Diurnal variations in the radiation components, upward and downward short (long) wavelengths, were also compared between the $\mathrm{CC}$ and $\mathrm{NC}$ sites (see Fig. 6a). Daytime downward shortwave radiation at the $\mathrm{CC}$ site largely exceeded that at the $\mathrm{NC}$ site, and downward longwave radiation at the NC site surpassed that at the $\mathrm{CC}$ site throughout the day. Thus, the forest canopy at the NC site both reduced the daytime insolation and emitted thermal downward radiation. At the CC site, the daytime net radiation exceeded $200 \mathrm{~W} / \mathrm{m}^{2}$, and the nighttime net radiation was below $-40 \mathrm{~W} / \mathrm{m}^{2}$ (Fig. 6b), causing radiative cooling. Nocturnal radiative cooling was not evident in the $\mathrm{NC}$ area. Therefore, large differences in Ts between the $\mathrm{CC}$ and $\mathrm{NC}$ sites were caused by the difference in radiation balance.

The one-dimensional concept of a heat budget may suggest that the higher Ts at the CC site induced larger sensible heating and increased the Ta. However, the differences in Ta between the two sites were small (Fig. 5a). According to the $2 \mathrm{~m}$ anemometer data at the CC site, daytime southerly winds of $3-4 \mathrm{~m} / \mathrm{s}$ and nocturnal east-southwesterly winds of $1-2 \mathrm{~m} / \mathrm{s}$ prevailed on many days without synoptic disturbances. These two wind directions corresponded to those downstream of the valley and from the upper slope, respectively. Local mountain valley circulation appeared to prevail over the sites, even in the core winter season, and horizontally mixed the surface boundary layer between the $\mathrm{CC}$ and NC sites; this reduced the Ta contrasts. This result confirms that radiation components are primary factors for evaluating the thermal conditions at the ground surface in a forested area and that air temperature is not a suitable indicator of thermal conditions for estimating the differences of frost heave occurrences with and without the forest.

Precipitation, snow cover, and soil moisture variations 
Under the relatively dry winter climate on the Pacific side of Japan, such as in the Ikawa area, precipitation amount and occurrences of snow cover are the key factors in changing the day-to-day variability of ground surface wetness and ground temperature that strongly govern frost heave processes. First, the altitudinal dependency of precipitation around the experiment site was examined. The daily precipitation amounts between the AMeDAS (755 $\mathrm{m})$ and the gauges at the $\mathrm{CC}$ and NC sites $(\sim 1200 \mathrm{~m})$ are compared in Figure 7 . Most of the precipitation amounts at the CC site exceeded those of the AMeDAS (see cross marks), indicating enhancement of orographic precipitation over the experimental sites. Large discrepancies in the daily precipitation between the two stations on December 21 and 27 and February 5, 12, and 17 were due to snow cover that accumulated on the orifice of the gauge without a heating system at the $\mathrm{CC}$ site, and meltwater was measured using the tipping bucket on the next day. As no direct measurements of precipitation type were made in this study, the occurrence of snowfall was estimated using the experimental formula proposed by Kondo (1994) using hourly Ta and relative humidity data. At the Ikawa-AWS site, precipitation occurred on 37 days. Of these, 50\% were estimated to be snow days, indicating that the experiment sites were located at a transitional altitude in relation to precipitation phases. The ratio of accumulated precipitation amounts, except for snow days, at the CC (NC) site to those at the AMeDAS station was 1.9 (1.2), indicating that altitudinal differences of $\sim 500 \mathrm{~m}$ doubled the precipitation amount and that forests decreased almost $40 \%$ of the amount. The forest at the NC site was composed of evergreen trees, which easily captured snow in their canopy. Nakai et al. (1993) estimated the interception rate in the Sakhalin fir forest in Japan at $\sim 50 \%$. Although a single rain gauge is not always adequate for evaluating areal precipitation in a forest, observation data qualitatively indicated that clear-cutting allowed for evaluation of the precipitation amount without the effect of interception, and the increase in winter precipitation amount by the orographic effect was found accordingly.

The presence of snow cover on the ground was detected on a daily basis using diurnal 
digital camera images, the estimated snow/rain threshold temperature, and temporal changes in Ts at both the CC and NC sites. Snow depth was also monitored using a sonic snow depth sensor. The sensor could only capture the condition at a point and was strongly affected by the drifting of snow; however, the data provided rough information on snow depth and its intra-seasonal changes at the site. Figure 8 shows the daily time sequences of snow cover and soil moisture, together with the daily precipitation variability observed at the AMeDAS station where the gauge was equipped with a heating element. Snow cover occurred on 30 days at the $\mathrm{CC}$ site and on 48 days at the $\mathrm{NC}$ site, with weekly scale intermittent at both sites (Fig. 8a). Major heavy snowfall events were identified three times during the analysis period on December 9, January 14, and February 13. However, the snow depth at the CC site was less than $20 \mathrm{~cm}$, indicating that shallow snow cover existed discontinuously through the winter season. Snow cover lasted 3-5 days longer at the NC site compared to the CC site, due to insufficient direct insolation under the canopy. As the warm spring season progressed, snowfall and snow cover did not occur beyond mid-February.

Figure $8 \mathrm{~b}$ shows temporal changes in soil moisture measured at $5 \mathrm{~cm}$ depth at the $\mathrm{CC}$ and $\mathrm{NC}$ sites. At the $\mathrm{CC}$ site, soil moisture gradually decreased from the beginning of winter with sporadic increases following precipitation. The diurnal variation in soil moisture showed a decrease in the daytime due to evaporation by insolation (figure omitted), indicating that the CC site could be attributable to direct seasonal-scale soil moisture decrease caused by direct radiation resulting from deforestation. In contrast, diurnal and intra-seasonal variation in soil moisture at the NC site was small. The difference in soil moisture between the two sites was not significant (mostly $<5 \%$ ), indicating that the increases in soil moisture due to nonintercepted precipitation at the CC site was compensated by evaporation due to stronger insolation. The existence of snow cover was another factor in keeping the soil moisture constant with similar levels at both sites. According to the indoor experiment by Meentemeyer and Zippin (1981), the critical thresholds of soil moisture for the formation of 
segregation ice are $20-25 \%$ with a porosity of $45-60 \%$ of typical Hapludutl soil. The actual soil materials in this site, brown forest soil with a porosity of $55-75 \%$ (Uchida and Nakamura, 1980), differ from previous studies, but the observed soil moisture records at the CC and NC sites remained above $25 \%$. This indicates that the soil was sufficiently wet to develop frost heaving at both sites throughout the season.

Occurrence of frost heave and transport

Figure 9 shows the relative motion of the surface as measured by the extensometers at the two sites throughout the target winter. Except for a small amount of diurnal noise, shown as negative values, which could not be corrected by the Ts data, clear daily signals were identified at the CC site for 25 days between December and February (Fig. 9a). Figure 10 shows the diurnal variations in the relative displacement detected by the extensometer for 19 representative days (the date in the legend corresponds to a day with a peak in the morning). Konko (1982) reported similar diagrams for needle ice growth in fair weather in an outdoor experimental flat area, where the frost started to develop after 21:00 hours and melted in the morning due to insolation on the slope. Up-down motion of the ground surface was also captured at the CC site by the digital camera. We determined that the signals were caused by the development of needle ice (daily frost heave) during the night and deformation due to morning melting at the top of the soil. Figure 11 shows an example of needle ice observed at the soil surface at the CC site.

The triangles $(\triangle)$ in Figure 9a show the days of needle ice occurrence at the CC site; they are also included at the bottom of Figure 8a to compare with snow cover periods. The occurrence of needle ice clearly coincided with non`snow cover days, except for January 1921 and February 27. These results agreed with those of previous studies, showing that needle ice at the soil surface tends to develop without snow cover (Berthling et al., 2001). For the 
exceptional cases of January 19-21, the camera observed shallow snow cover over the sensor of the extensometer and also showed that a no-snow area had extended from the upper slopes. Therefore, we assume that a snow cover hung over the soil surface in that period, and that frost may have developed in the gap between the soil surface and the bottom of the snow cover. On February 27, a shallow snow cover of only a few centimeters occurred, and frost may have developed under this snow cover. The signal on February 17 was twice larger than those on other days, and the surface on January 26 did not drop down in the daytime with a corresponding rise the following night. A continuation of the surface temperature below $0^{\circ} \mathrm{C}$ till noon with sufficient soil moisture could have resulted in the development of needle ice, as explained by Branson et al. (1996). We do not analyze those unusual days hereafter (they are not shown in Fig. 10).

The relative motion (up-down) of the ground surface at the NC site is illustrated in Figure 9b. The time sequence showed no evident diurnal variations (contrast with Fig. 9a), but ascending and descending motions with a longer timescale of several days occurred three times. As the diurnal variation in air temperature did not differ between sites (Fig. 5a), the reduction in radiative cooling clearly suppressed the occurrence of needle ice. The amplitudes of the up-down motion at the NC site were five times smaller than those in the needle ice events observed at the CC site. Major ascending periods are marked A to C. Note that period A coincided with non-snow cover periods at both the $\mathrm{CC}$ and $\mathrm{NC}$ sites, and periods $\mathrm{B}$ and $\mathrm{C}$ were the same for the CC site. Those coincidences suggest an important hypothesis, that the signals may indicate the gradual development of frost heaving in the soil layer, associated with ice lenses, during non-snow-covered or shallow snow-covered periods with successive nights of radiative cooling.

Downslope displacement of ground surface sediments at the CC site was clearly greater than that at the NC site; cumulative displacements of the sediment in the period from December 27, 2012 to March 28, 2013 were 132 and $3 \mathrm{~mm}$ at CC and NC, respectively). 
Because the depth of the freezing layer in the NC site was deeper than that at CC, we cannot simply conclude that the sediment transport rate at CC was more active than that at NC. However, our monitoring results demonstrated that the difference in the microclimate associated with clear-cutting not only changed the type of freeze-thaw process but also changed the frequency of surficial sediment transport.

\section{Discussion}

Synoptic weather conditions caused needle ice formation

Observations revealed that needle ice frequently occurred on clear-cut slopes without snow cover under the conditions of sufficient soil moisture and nocturnal radiative cooling. However, days with and without needle ice were intermixed even in the snow-free periods

(Fig. 8a). The days without precipitation or snow cover were classified into two groups: group $\mathrm{X}$, with 21 days of frost occurrence (marked $\triangle$ in Fig. 8a) and group Y, with 23 days without a frost signal. Temperature/humidity and radiation components were compared between the two groups. Figure 12 shows the averaged diurnal variations in temperature/humidity (upper) and radiation (lower) components for groups X (left) and Y (right), where a time sequence starts from 06:00 and lasts for 18 successive hours including a first night of frost (non-frost) development. The surface temperature $\left(\mathrm{Ts}_{\mathrm{s}}-0 \mathrm{~cm}\right)$ largely exceeded the $\mathrm{Ta}$ in the daytime, but dropped below the Ta in the night, indicating upward heat flow due to radiative cooling at the ground surface. During the nights when needle ice developed (Fig. 12a), Ta and Ts $-0 \mathrm{~cm}$ dropped below $-4^{\circ} \mathrm{C}$. The soil temperature at $5 \mathrm{~cm}$ depth $\left(\mathrm{Ts}^{-} 5 \mathrm{~cm}\right)$ remained above $0^{\circ} \mathrm{C}$, confirming that soil moisture could advect upward in the liquid phase to cause needle ice. During nights without frost (Fig. 12b), the surface temperature became warmer and the Ta stayed $\sim 0^{\circ} \mathrm{C}$ until midnight, suggesting that warm air mass intrusion had compensated 
for radiative cooling at the ground surface and disturbed freezing. For the surface radiation components (Fig. 12, lower), nocturnal net radiation remained negative in both groups, indicating prevailing radiative cooling. However, the value was smaller for the non-frosted days because of the $33 \mathrm{~W} / \mathrm{m}^{2}$ increasing downward longwave radiation on average through the night (Fig. 12d). At the same time, relative humidity remained over $65 \%$ during the night. The soil moisture data contained missing days, but the average soil moisture did not show a large difference between the groups (figure omitted).

Synoptic-scale surface pressure patterns were also compared between the two groups using JMA surface weather maps. For group X, 9 days were associated with a traveling highpressure system, 6 days with a transitional period of a weakening winter monsoon between a west high-pressure and east low-pressure pattern, 4 days with a west high-pressure and east low-pressure system, and 2 days with a traveling low-pressure system in the Sea of Japan sector. For group Y, 11 days were associated with a traveling low-pressure system or polar front, 7 days with a west high-pressure and east low-pressure pattern, and 5 days with a traveling high-pressure system. Consequently, $71 \%$ of the frost days correlated with a traveling high-pressure system or the transitional pattern of a weakening winter monsoon, whereas $78 \%$ of the non-frost days correlated with synoptic disturbance or winter monsoon conditions. The daytime surface wind speed also increased during the frost days, confirming active local circulation during fair weather under a high-pressure system. The pressure pattern of the winter monsoon (west high pressure and east low pressure) sometimes causes cloud bands on the Pacific side due to low-level wind convergence behind the central mountain ranges (Nishina, 1984). Evidence gathered in the surface meteorological parameters and weather maps suggests that the prevailing cloudy weather with warmer and moist air intrusion associated with synoptic disturbance is a primary factor in suppressing the development of needle ice during nighttime. 
Surface thermo-hydrological conditions affecting needle ice growth

Nocturnal development of needle ice showed various growth speeds depending on the day (Fig. 10). Interrupted growth conditions also play an important role for sediment inclusion in needle ice (Branson et al., 1996). In this section, plausible surface thermo-hydrological conditions affecting needle ice development are examined using a case study of the CC site. In group X, an additional four unique groups were defined, as shown in Figure 13. Group A represents days with an early start of growth, such as December 13, January 1, and February 21 (solid thick lines with markers), and Group B represents those with a delayed start, such as December 24 and February 1 (dashed lines). Group C represents the days showing slow growth speed and where growth ceased, such as January 5, 8, and 30 (solid thin line), and Group D was a day with an extreme delay in growth, i.e., December 26 (chain line).

The 3 days in Group A corresponded with traveling anticyclones in the synoptic weather chart, and the diurnal temperature variability was similar to Figure 12a. In particular, the nocturnal air temperature and downward longwave radiation were below the averages for the frost days. The relative humidity on December 13 and February 21 was below 50\% through the night. On December 13, soil moisture at $5 \mathrm{~cm}$ was $10 \%$ higher than the average, but significant increases were not found (see Fig. 8a). The notable aspects of Group A were that all 3 days occurred within 2 days of snow cover disappearance at the CC site (black triangles at the bottom of Fig. 8a), and 2 days were associated with snow cover in the forest (NC site). The daytime micro-anemometer data before the frost nights on December 12 and 31 clearly showed an earlier shift of wind direction from southerly (from the valley) to easterly (from the upper slope) after sunset, with weakening wind speed. According to the evidence, we speculate that sensible heating by gravitational cold drainage flow from the snow-covered mountain slopes under calm and fair weather conditions compensated for the 
soil heat conduction and helped the earlier development of needle ice. For Group B, extratropical cyclones were analyzed in the Sea of Japan on the weather map, and the ground surface temperature was found to be $\sim 0^{\circ} \mathrm{C}$ until 23:00 hours. Downward longwave radiation increased before midnight to elevate the net radiation (and reduce radiative cooling; Fig. 14). These data suggest that nocturnal cloudy weather associated with the southern warm sector of a traveling low pressure system prevented surface radiative cooling and delayed the start of needle ice growth. For Group C, weather charts showed a prevailing high-pressure system without increases in downward longwave radiation during the night. However, on January 5 and 8, the soil moisture was 10\% less than the average (missing data for Jan. 30), as shown in Figure 13. Thus, we speculate that a deficit in soil moisture caused a slowdown in frost growth in the middle of the night. December 26, categorized as Group D, showed a large delay in needle ice growth. The development of an extratropical cyclone over the Sea of Japan was analyzed on a weather map, and positive values of Ta were recorded after midnight. Micro-anemometer data showed prevailing strong southeasterly winds through the night. These data suggest that synoptic-scale warm air-mass advection, associated with a warm sector of the cyclone, prevented needle ice growth.

Finally, we checked the consistency of nocturnal needle ice development by calculating the heat required to grow needle ice in it at the ground surface. As the latent heat of melting ice is $0.334 \times 10^{6} \mathrm{~J} / \mathrm{Kg}$, forming an ice layer for 10 hours with a $1 \mathrm{~cm}$ thickness, as in the cases in Figure 10 consumes $93 \mathrm{~W} / \mathrm{m}^{2}$. The actual ice needles are not a continuous ice layer but are formed of less dense vertical filaments. The length of the needles may also be underestimated in Figure 10. If the density of the ice were $50 \%$, the order of the required latent heat energy loss to form the needle ice would be $\sim 50 \mathrm{~W} / \mathrm{m}^{2}$. Observation data showed that clear-cutting of the canopy resulted in enhanced radiative cooling of $45 \mathrm{~W} / \mathrm{m}^{2}$ (Fig. $6 \mathrm{~b}$ ), and when cloudy weather conditions increased the downward longwave radiation by $33 \mathrm{~W} / \mathrm{m}^{2}$, needle ice did not grow (Fig. 12c,d). Accordingly, the order of the required energy loss from 
the surface to grow needle ice during a night agreed with the energy balance determined by the radiation component. Figure 15 shows the relation between the morning maximum relative motion and the nighttime (22:00-07:00 hours) averaged net radiation in the cases of needle ice growth days shown in Figure 10. The days in Groups C and D with less development of needle ice, as expected by the abnormal synoptic weather or soil moisture conditions, were excluded. A tendency for less radiative cooling to cause smaller ice needle growth is clear (correlation was significant at the $1 \%$ level). Soil heat flux (G) is another factor that suppresses needle ice development. Even the temperature gradient was less than $1^{\circ} \mathrm{C}$ at a $5 \mathrm{~cm}$ distance during the nights with frost development (Fig. 12a), G was estimated to vary from 6 to $40 \mathrm{~W} / \mathrm{m}^{2}$ when thermal conductivity $(\lambda)$ changes depending on soil type and wetness, such that $\lambda$ is $0.3(2.0) \mathrm{W} \mathrm{m}^{-1} \mathrm{~K}^{-1}$ for dry (wet) soil or clay (Kondo, 1994). However, soil type is the same at the observation point, and soil moisture did not change day by day during snow-free periods (Fig. 8b) and so $\lambda$ also does not change day by day. Then, the dayto-day variety in needle ice growth, as shown in Figure 10, is not attributable to soil heat flux changes.

Effect of freeze-thaw cycles on downslope sediment transport

Soils with fine sediment are generally susceptible to frost heave as well as the downslope movement of soil, since small pores between fine sediments can hold water and keep high moisture content (Higashi and Corte, 1971; Harris et al., 1993, Matsuoka, 2001). The soils at both the CC and NC sites were characterized by a smaller amount of fine sediment (i.e., clay and silt, $<10 \%$ in weight; Fig. 3) compared with monitoring sites in previous studies (usually >20\%; Meentemeyer and Zippin, 1981; Matsuoka et al., 2003; Kværnø and Øygarden, 2006). Therefore, the soils at the CC and NC sites were considered to be less susceptible to frost heave. Soil water content is an important factor controlling the occurrence of freeze-thaw 
activity (Hall and Thron, 2011). Because the soil water content in the Ikawa region is always high (generally $25-40 \%$ ), affected by an abundant water supply from sporadic precipitation that causes shallow snow cover due to the high elevations (Fig. 8b), water content was not likely a limiting factor for the occurrence of frost heave in the area. The frost heave activity in the CC area was higher than that in the NC area, despite the water content in the CC area being below that at NC (Figs. 8b, 9), also supporting the idea that water content did not severely limit frost heave activity. Such humid soil conditions in the Ikawa region facilitated frequent frost heave and active downslope sediment transport in the study site despite the lack of fine sediment.

Displacement of ground surface sediment along the downslope direction can be expressed as a function proportional to the amount of frost heave (Higashi and Corte, 1971; Matsuoka, 1998b; Matsuoka, 2001). Therefore, the cumulative amount of frost heave can be used as an index for discussing downslope sediment transport. The cumulative amount of frost heave along directions at a right angle to the ground surface, calculated from the sum of the positive displacement of the ground surface in each freeze-thaw cycle (Fig. 9) from December 27, 2012 to March 28, 2013 (analysis period for sediment movement in the downslope direction; Fig. 16), was 185 and $10 \mathrm{~mm}$ at $\mathrm{CC}$ and NC, respectively. Under the assumption that sediment drops vertically after being lifted by frost heave, displacement along the slope direction, calculated from the cumulative amount of frost heave multiplied by the slope gradient ( $\sin 38^{\circ}$ and $\sin 35^{\circ}$ for $\mathrm{CC}$ and $\mathrm{NC}$, respectively), was 144 and $7 \mathrm{~mm}$ for $\mathrm{CC}$ and $\mathrm{NC}$, respectively. These values roughly correspond to the sediment displacement along the slope direction directly obtained from camera image analyses (132 and $3 \mathrm{~mm}$ for CC and NC, respectively; Fig. 16). Thus, the higher amount of frost heave in the $\mathrm{CC}$ results in greater downslope sediment transport.

At CC, sediment transport events were also observed on days without freeze-thaw activities. Some of the transport events took place during rainfall but others occurred on days 
without rainfall. Such non-periglacial and non-rainfall sediment movements have been reported in previous studies (Sasaki et al., 2000; Matsubayashi and Tamura, 2005; Sonoda and Okunishi, 2005). Swelling and shrinking of soil associated with changes in the ground water content induce downward (sometimes upward) sediment transport as soil creep (Sasaki et al., 2000; Sonoda and Okunishi, 2005). Although the freeze-thaw frequency in January 2013 was higher than that in February 2013 at site CC (Fig. 9), the velocity of the sediment transport in February exceeded that in January 2013 $(2.0$ and $1.1 \mathrm{~mm} /$ day, respectively). Active sediment transport in the latter half of the winter has also been recorded by previous studies in Japan (Ko, 1976). The repetition of freezing and thawing reduces soil strength by disturbing the soil structure (Ferrick and Gatto, 2005; Sonoda and Okunishi, 2005). Therefore, disturbance of the soil structure in early winter may facilitate sediment transport in late winter. Sediment transport by non-periglacial processes was included in the displacement directly assessed from camera images (132 mm). As a result, the displacement of sediment along the slope direction estimated from the height of frost heave (144 $\mathrm{mm}$ at CC) exceeded the actual displacement when we focus on the periglacial processes. This results the possibility of sediment being lifted up by needle ice drop to a slightly higher location. This does not agree with some previous studies concluding downward movement of sediment from the vertical direction (e.g., Higashi and Corte, 1971; Matsuoka, 2001). One potential factor affecting such disagreement is error in the measurement and analysis, such as a limitation in the resolution of the camera images (1-2 $\mathrm{mm} /$ pixel in this study) and the accuracy of extensometers. Further detailed observations are needed to clarify the motion of sediment associated with freeze-thaw cycles.

Needle ice creep is sometimes followed by secondary sediment movement as dry ravel, which is less active in the frost creep areas (Sawaguchi, 1987, Imaizumi et al., 2015). Our interval cameras in the CC area (needle ice creep-dominated) also captured the disappearance of ground surface sediment associated with dry ravel. Therefore, the 
difference in the type of freezing and thawing between CC and NC (frost creep-dominated) also affects sediment transport activity after thawing.

\section{Conclusions}

Clear-cut deforestation on a steep mountain slope in the Ikawa University Forest, located in a temperate climate zone in south central Japan, provided an opportunity for intensive observations of frost heaving for comparison with forested conditions. Micrometeorological observations were conducted with soil moisture and surface level monitoring in both forested and deforested areas simultaneously throughout one winter season in 2012/13. Deforestation abruptly changed the surface radiation budget, such that the increase in direct insolation increased the morning ground surface temperature, and the reduction of downward longwave radiation enhanced nighttime radiative cooling. However, surface air temperatures between the two sites did not differ significantly due to the horizontal mixing of air by local circulation. Thus, deforestation could enhance the effects of cloudiness associated with weather changes on the surface energy budget. Precipitation increased on the ground surface of the clear-cut site due to the absence of interception by the canopy. However, the soil moisture at a $5 \mathrm{~cm}$ depth did not differ largely from the $\mathrm{NC}$ site with a gradual intraseasonal decreasing trend. We attributed this to the enhancement of evaporation by daytime direct insolation, which compensated for the increase in precipitation. One of the key parameters for controlling the subsurface hydrological condition was the occurrence of shallow snow cover, intermittently provided by traveling extratropical cyclones that could maintain the soil moisture, which also determined the days with frost heaving.

Extensometers and digital interval cameras were used to detect the occurrence of frost heaving. In the deforested area, diurnal signals of surface level changes were found in snowfree periods, indicating needle ice development at the surface during the night and its 
subsequent collapse due to direct insolation in the morning. According to the analysis of surface weather maps and surface radiation/temperature composites, cloudy weather with warmer and moist air intrusion associated with synoptic disturbances prevented the occurrence of needle ice even in the snow-free periods. Also, the day-to-day variability in needle ice growth length and nighttime net radiation showed a significant correlation, such that larger radiative cooling caused longer needle ices. Thus, the variability in downward longwave radiation associated with cloudy weather was a primary factor in controlling frost heaving conditions after deforestation. Some exceptional cases were found, including rapid development of needle ice just after snow cover expired and needle ice growth stopping during a night with a smaller amount of soil moisture. The micro scale function of how soil moisture and the atmospheric boundary layer affect needle ice growth around the periphery of snow cover needs to be investigated further.

In the forested area, weekly surface level changes with smaller amplitudes dominated over diurnal signals. As the timing of surface rising coincided with snow-free periods, we speculated that this movement was due to growth of ice lenses within the soil. As mass movement speed and its depth differ between needle ice creep and frost creep by ice lenses (e.g., Matsuoka, 1998b; Matsuoka, 2001), the results suggest that deforestation induces a different style of surface motion in the mountain areas of Japan. Unfortunately, the observation network did not allow us to deploy enough sensors to analyze the formation of ice lenses in the soil; detailed studies at the NC site were postponed until the next research framework.

Most previous studies examined frost heave processes in high-elevation areas above timber lines or in Arctic areas. This study focused on frost heaving on steep mountain slopes with forests, where fair-weather conditions prevail behind the mountains, blocking the winter monsoon. Deforestation fundamentally changed the radiation balance at the surface and shifted the temporal scale of frost development on a daily basis. In the winter of $2012 / 13$, the 
distance of ground surface movement due to needle ice development was estimated to be 100$150 \mathrm{~mm}$ in $\mathrm{CC}$ vs $\sim 0 \mathrm{~mm}$ in $\mathrm{NC}$ sites, demonstrating that strong control of ground cover on frost processes. Assessing its year-to-year variability due to weather changes is an important issue for the future. The sporadic snow cover and weather that control the frost heaving conditions were provided by coastal extratropical cyclones; their activity is associated with hemispheric-scale climate variability, and influences the precipitation phases (rain or snow) in central and eastern Japan (e.g., Ueno, 1993; Sato et al., 2012). Therefore, we need longterm monitoring of frost heaving with micrometeorological data in various winter conditions by means of hemispheric-scale cyclone activities for the purpose of monitoring global warming effects.

Acknowledgements - This study was supported by the Japanese Alps (JALPS) interuniversity cooperative project under the Ministry of Education, Culture, Sports, Science and Technology. Observations were supported by the technical staff members Mr. Endo and Mr. Ueji in the Ikawa University Forest, and we appreciate all of the staff who established and maintain the observation system. We also thank to two reviewers for their very constructive comments. 


\section{References}

Anderson RS. 2002. Modeling the tor-dotted crests, bedrock edges, and parabolic profiles of high alpine surfaces of the Wind River Range, Wyoming, Geomorphology 46: 35-58.

Benedict JB. 1970. Downslope soil movement in a Colorado alpine region: rates, processes, and climatic signature, Arctic and Alpine Research 2: 165-226.

Benda L. 1990. The influence of debris flows on channels and valley floors in the Oregon Coast Range, U.S.A., Earth Surface Processes and Landforms 15: 457-466.

Berthling I, Eiken T, Sollid JL. 2001. Frost heave and thaw consolidation of ploughing boulders in a mid-alpine environment, Finse, Southern Norway, Permafrost and Periglacial Processes 12: 165-177.

Boelhouwers J. 1998. Environmental controls on soil frost activity in the Western Cape Mountains, South Africa, Earth Surface Processes and Landforms, 23: 211-221.

Boelhouwers J, Holness S, and Sumner P. 2000. Geomorphological characteristics of small debris flows on Junir's Kop, Marion Island, maritime sub - Antarctic, Earth Surface Processes and Landforms 25: 341-352.

Boelhouwers J, Holdess S, Summer P. 2003. The maritime subantarctic: a distinct periglacial environment, Geomorphology 52: 39-55. Doi:10.1016/S0169-555X(02)00247-7

Branson J, Lawler DM, Glen JW. 1996. Sediment inclusion events during needle ice growth: a laboratory investigation of the role of soil moisture and temperature fluctuiations. Water Resources Research 32: 459-466.

Brardinoni F, Church M. 2004. Representing the landslide magnitude-frequency relation: Capilano River Basin, British Columbia, Earth Surface Processes and Landforms, 29: 115124. DOI: 10.1002/esp.1029

Edeso JM, Merino A, González MJ, Marauri P. 1999. Soil erosion under different harvesting managements in steep forest lands from northern Spain, Land Degradation \& Development 10: 79-88. DOI: 10.1002/(SICI)1099-145X(199901/02)10:1<79::AIDLDR324>3.0.CO;2-4

Ferrick M.G., Gatto L. W. 2005. Quantifying the effect of a freeze-thaw cycle on soil erosion: laboratory experiments, Earth Surface Processes and Landforms 30: 1305-1326. DOI: 10.1002/esp.1209

Gabet EJ, Dunne T. 2002. Landslides on coastal sage-scrub and grassland hillslopes in a severe El Niño winter: The effects of vegetation conversion on sediment delivery. Geological Society of America Bulletin 114: 983-990. DOI: 10.1130/00167606(2002) $114<0983:$ LOCSSA>2.0.CO;2 
Guthrie RH. 2002. The effects of logging on frequency and distribution of landslides in three watersheds on Vancouver Island, British Columbia, Geomorphology 43: 273-292. DOI:10.1016/S0169-555X(01)00138-6

Hall K. and C. Thorn. 2011. The historical legacy of spatial scales in freeze-thaw weathering: Misrepresentation and resulting misdirection, Geomorphology 130: 83-9.

Harris C, Gallop M, Coutard JP. 1993. Physical modelling of gelifluction and frost creep: some results of a large-scale laboratory experiment. Earth Surf. Processes Landforms 18, 383-398.

Haussmann N, McGeoch M. and Boelhouwers J. 2009. Interactions between a cushion plant (Azorella selago) and surface sediment transport on sub-Antarctic Marion Island, Geomorphology 107: 139-148.

Higashi A, Corte AE. 1971. Solifluction: a model experiment, Science, 171: 480-482. DOI: 10.1126/science.171.3970.480.

Imaizumi F, Sidle RC. Tsuchiya S. Ohsaka O. 2006. Hydrogeomorphic processes in a steep debris flow initiation zone, Geophysical Research Letters 33: L10404

Imaizumi F, Sidle RC, Kamei R. 2008. Effects of forest harvesting on the occurrence of landslides and debris flows in steep terrain of central Japan, Earth Surface Processes and Landforms 33: 827-840.

Imaizumi F, Hattanji T, Hayakawa YS. 2010. Channel initiation by surface and subsurface flows in a steep catchment of the Akaishi Mountains, Japan, Geomorphology, 115: 32-42.

Imaizumi F, Ueji Y. 2012. Soil movement of artifitial forests located in steep mountain area and its countermeasures using thinned woods, Journal of the Japanese Forest Society 94: 24-30. (in Japanese, with English abstract)

Imaizumi F, Sidle RC, Togari-Ohta A. Shimamura M. 2015. Temporal and spatial variation of infilling processes in a landslide scar in a steep mountainous region, Japan, Earth Surface Processes and Landforms, 40: 642-653. DOI: 10.1002/esp.3659

Ko TB. 1976. Experiment about the destruction and the erosion on the hill-side caused by the frost pillars and the frost heaving. Journal of the Japanese Forest Society 58: 23-27. (in Japanese)

Kondo J. 1994: Meteorology of the Water Environment, -Water and Heat Balance of the Earth's Surface, Asakura Shoten Press, Japan, pp348 (in Japanese).

Konko T. 1982. Studies on the growth of frost pillars, Tech. Bull. Fac. Hort. Chiba Univ., 30: 61-86. (in Japanese, with English abstract)

Konrad JM, Duquennoi C. 1993. A model for water transport and ice lensing in freezing soils. Water Resources Research 29: 3109-3124. DOI:10.1029/93WR00773.

Kværnø SH, Øygarden L. 2006. The influence of freeze-thaw cycles and soil moisture on aggregate stability of three soils in Norway, Catena, 67: 175-182. 
Matsubayashi T, Tamura T. 2005. Mode and Rate of Soil Creep by Soil Horizons: Device of a monitoring method and its application to forest covered hillslopes in humid temperate climate. Journal of Geography 114: 751-766.

Matsuoka N. 1998a. The relationship between frost heave and downslope soil movement: field measurements in the Japanese Alps, Permafrost and Periglacial Processes 9: 121-133.

Matsuoka N. 1998b. Modelling frost creep rates in an alpine environment, Permafrost and Periglacial Processes 9: 397-409.

Matsuoka N. 2001. Solifluction rates, processes and landforms: a global review, EarthScience Review 55: 107-134. DOI: 10.1016/S0012-8252(01)00057-5

Matsuoka N, Abe M., Ijiri M. 2003. Differential frost heave and sorted patterned ground: field measurements and a laboratory experiment, Geomorphology 52, 73-85.

Meentemeyer V, Zippin J. 1981. Soil moisture and texture controls of selected parmafrosts of needle ice growth, Earth Surface Processes and Landforms 6: 113-125.

Nakai Y, Sakamoto T, Terajima T, Kitamura K. 1993. A study on evaporation of snow intercepted by forest canopy. Journal of the Japanee Forest Society 75: 191-200. (in Japanese with abstract in English)

Nel W, Boelhouwers JC, and Zilindile MB. 2009. The effect of synoptic scale weather systems on sub-surface soil temperatures in a diurnal frost environment: Preliminary observations from sub-antarctic marion island. Geografiska Annaler 91: 313-319.

Nishina J. 1984. An orographic effect on the cloud distribution around the central Japan under the winter monsoon situation. Geographical Review of Japan. 57. 329-348.

Outcalt SI. 1971. An algorithm for needle ice growth. Water Resources Research 7: 394400.Roberts RG, Church M. 1986. The sediment budget in severely disturbed watersheds, Queen Charlotte Ranges, British Columbia, Canadian Journal of Forest Research 16: 1092-1106.

Sawaguchi S. 1987. Slow mass-movement processes caused by freezing and thawing on a bare ground as a result of humnan impact at the Kitakami mountains in north Japan, Geographical Review of Japan (Series A) 12: 795-813. (in Japanese, with English abstract)

Sasaki Y, Fujii A, Asai K. 2000. Soil creep process and its role in debris slide generationfield measurements on the north side of Tsukuba Mountain in Japan, Engineering Geology 56: 163-183. DOI: 10.1016/S0013-7952(99)00141-6

Sato K, Ueno K, Nanko K, Shimizu S. 2012. Rainfall tendency in winter Sugadairakogen Highlands, Nagano Prefecture, J. Japan Soc. Hydrol. and Water Resour. 25: 217-289. (in Japanese, with English abstract)

Seto M, Sue A, Sawada Y, Sone T, Tamura T. 2010. Laboratory experiment of surface stone displacement under freeze-thaw conditions, Bulletin of Geo-Environmental Science 12: 1937. (in Japanese. with English abstract)

Smith D. J. 1988. Rates and controls of soil movement in a solifluction slope in the Mount Rae area, Canadian Rocky Mountains, Z. Geomorphol. N. F. Suppl. 71: 25-44. 
Sonoda M, Okunishi K. 2005. Correlation between soil creep behavior and soil moisture change on a forest slope of weathered granite in West-Japan. Transactions, Japanese Geomorphological Union 26: 105-129.

Suzuki H. 1962. The classification of Japanese climates, Geographical Review of Japan (Chirigaku Hyoron) 35: 205-211. (in Japanese, with English abstract)

Uchida K, Nakamura M. 1980. Soil in Ohi River basin, Biological Studies on Landsliderelated Sediment Transport and Environment Conservation in Mountain Region I, 49-84 (in Japanese).

Uchida K, Maita H, Itho K, Kuroda Y. 1992. Studies on environmental condition for forest with the south and the north slopes of the high mountain (1): the relation among freezing and thawing of the soil, weather, and topographical situation on frost stand, Bulletin of Tsukuba University Forests 8: 107-122. (in Japanese, with English summary)

Ueno K. 1993. Inter-annual variability of surface cyclone tracks, atmospheric circulation patterns, and precipitation patterns in winter, J. Meteor. Soc. Japan 71: 655-671.

Ueno K, Rui D, Nakamura D, Ito Y, Yamashita S. 2010. Behavior of vegetation protection slopes during freezing and thawing. Soils and Foundations 5: 413-424. (in Japanese, with English abstract)

Vieira GT, Mora C, Ramos M. 2003. Ground temperature regimes and geomorphological implications in a Mediterranean mountain (Serra da Estela, Portugal), Geomorphology 52: $57-72$.

Williams P, Smith MW. 1989. The Frozen Earth. Cambridge University Press, pp. 306. 


\section{Table and Figure captions}

Table 1 Plot list in clear-cut (CC) and non-cut (NC) sites with parameters of observation and sensor heights

Figure 1 Location of Ikawa University Forest (left) and plots in clear-cut (CC) and non-cut (NC) areas (right)

Figure 2 Disposition of monitoring instruments in each plots, with diagrams of plan view below.

Figure 3 Particle size distribution at monitoring plots.

Figure 4 Sky factors by fisheye lens at a) CCS in the CC area and b) COS in the NC area .(photo taken on Nov. 11, 2012)

Figure 5 Diurnal variation of a) air temperature at $2 \mathrm{~m}$ high and b) ground surface temperature estimated from upward long-wave radiation averaged over the observation period (December 2012 to March 2013); solid and dashed lines correspond to the CC and NC sites, respectively.

Figure 6 Same as for Fig. 5, except for a) short (S)- and long (L)-wave downward ( $\downarrow$ ) and upward $(\uparrow)$ components, and b) net radiation in the $\mathrm{CC}$ and $\mathrm{NC}$ sites.

Figure 7 Scattering diagram of daily precipitation between Ikawa AMeDAS and CC $(\times) / \mathrm{NC}$ (O) sites.

Figure 8 a) Intra-seasonal variation of daily maximum snow depth at $\mathrm{CC}$ site $(\bigcirc)$ and snow cover day at $\mathrm{NC}$ site (black bar) and CC site (cross mark). Triangle marks below the $0 \mathrm{~cm}$ level indicate days with frost heaving occurred at CC site ( $\boldsymbol{\Delta}$ corresponds to a day for Group A with early starting of needle ice as explained in Fig. 10).

b) The same for a) but daily soil moisture at $5 \mathrm{~cm}$ level in NC site (dashed line) and CC site (solid line). Vertical bars indicate daily precipitation amount at the AMeDAS station.

Figure 9 Day-to-day changes of ascending surface level measured by the extensiometer at a) $\mathrm{CC}$ site and b) $\mathrm{NC}$ site. A to $\mathrm{C}$ in b) indicate periods with ascending the surface level.

Figure 10 Diurnal variation of relative motions for the frost days 
Figure 11 Photograph of needle ice in site CC taken on Jan. 28, 2013.

Height of the needle ice was about $1.5 \mathrm{~cm}$.

Figure 12 Comparison of air temperature (Ta), surface temperature $(\mathrm{Ts} 0 \mathrm{~cm})$, soil temperature at $5 \mathrm{~cm}$ deep (Ts $-5 \mathrm{~cm}$ ) and relative humidity at $2 \mathrm{~m}(\mathrm{RH})$ composed for frosted (a) and non-frosted (b) days in upper figures. The same for downward shortwave radiation $(\mathrm{S} \downarrow)$ ), long-wave radiation ( $\downarrow \downarrow)$ and net radiation ( $\mathrm{nn}$ ) for frosted (c) and non-frosted (d) days in lower figures.

Figure 13 Diurnal variation of relative distances for typical days in four groups (solid thick lines as Group A; dashed lines as B, solid thin lines as C; and chain line as D)

Figure 14 Nocturnal variation of net radiation $(\mathrm{Rn})$ and downward long-wave radiation $(\mathrm{Ld})$ on Dec. 24 and Feb. 1

Figure 15 Relations between the nocturnal averaged net radiation and morning maximum relative motion for the days in Fig. 10, except for Dec. 16, Jan. 5, 8, and 30.

Figure 16 Cumulative displacement of the ground surface sediment along slope direction obtained from camera image analysis. Dashed line sections indicate no data periods because of low quality of the images or snow cover. 
Table 1

\begin{tabular}{|cccc|}
\hline Area name & \multicolumn{1}{c}{ CC } & NC \\
\hline \hline $\begin{array}{c}\text { Parameters of } \\
\text { observation }\end{array}$ & $\begin{array}{c}\text { Sensor } \\
\text { height }\end{array}$ & Plot name Plot name \\
\hline \hline $\begin{array}{c}\text { Air temperature } \\
\text { and Humidity }\end{array}$ & $1.5 \mathrm{~m}$ & CCS & COS \\
\hline Radiation & $2.0 \mathrm{~m}$ & CCS & COS \\
\hline Soil moisture & $-5.0 \mathrm{~cm}$ & CCR & COR \\
\hline Camera & Near surface & CCR & COR \\
\hline Extensometer & Near surface & CCR & COR \\
\hline Rain gauge & Near surface & CCS & COS \\
\hline Snow depth & $1.0 \mathrm{~m}$ & CCR & COR \\
\hline
\end{tabular}

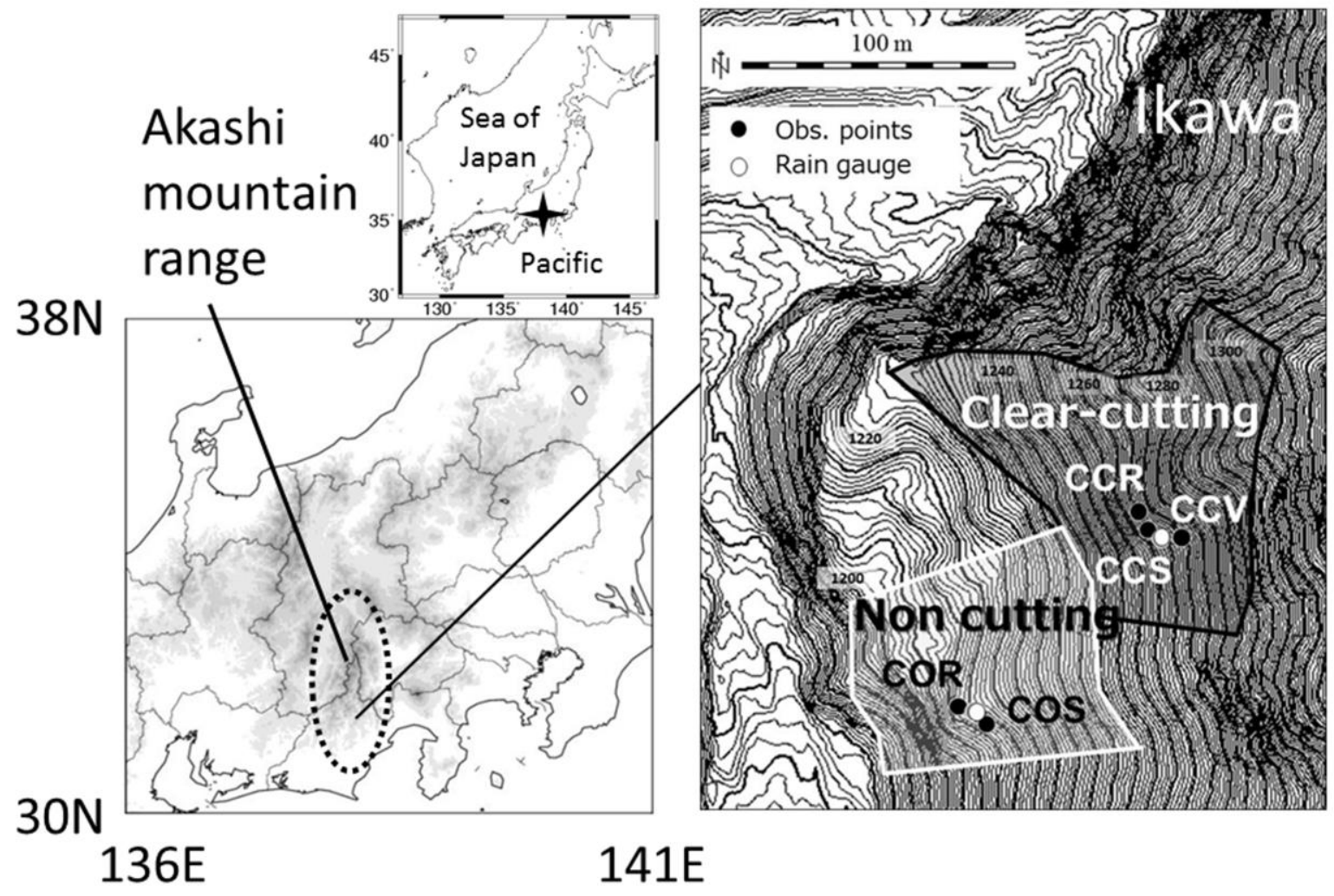

Fig.1 

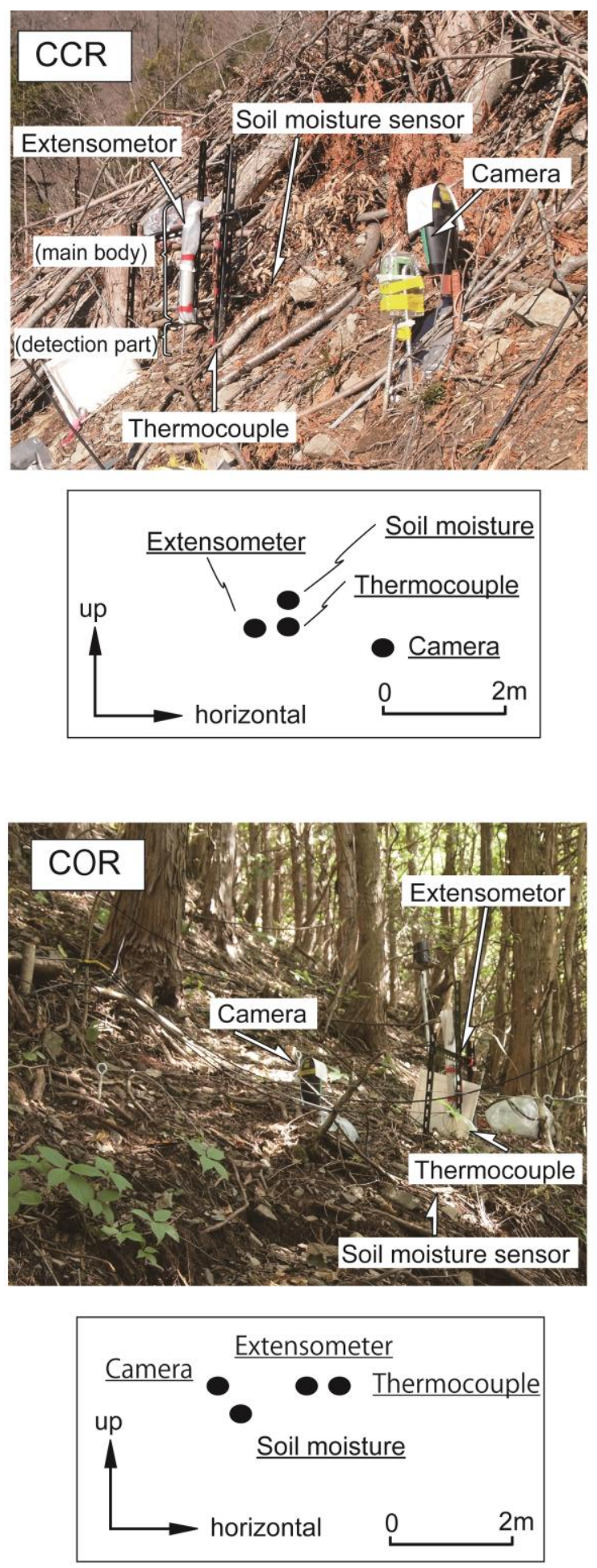
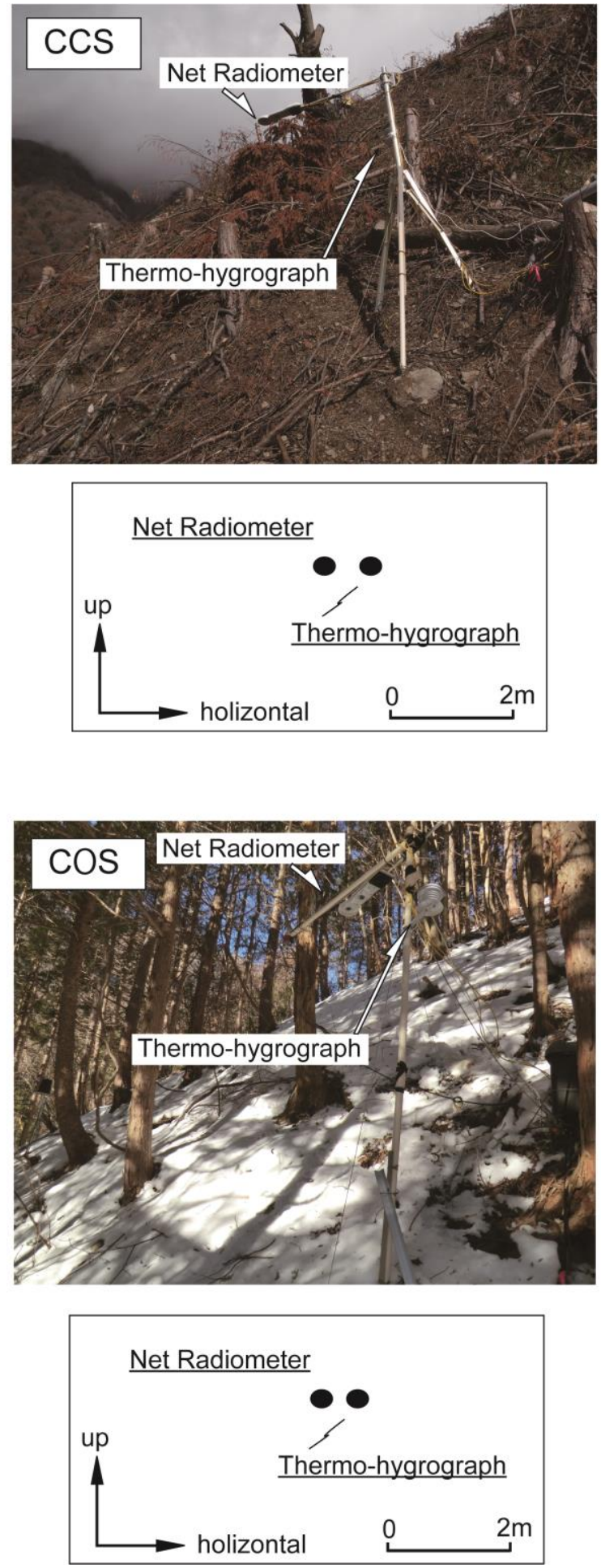

Fig.2 


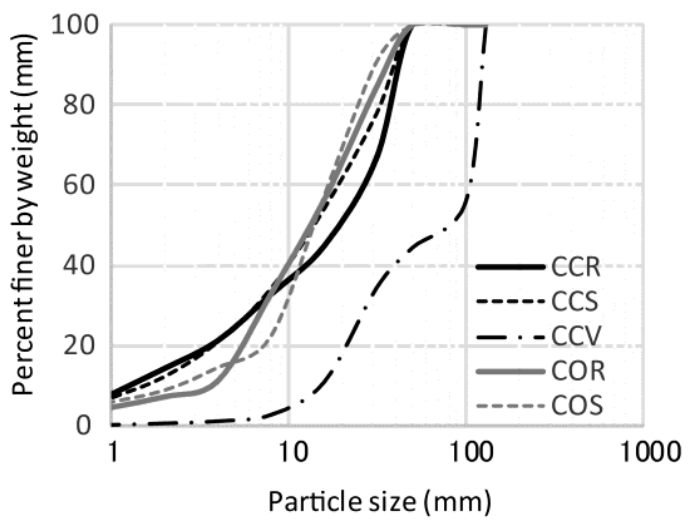

Fig. 3 


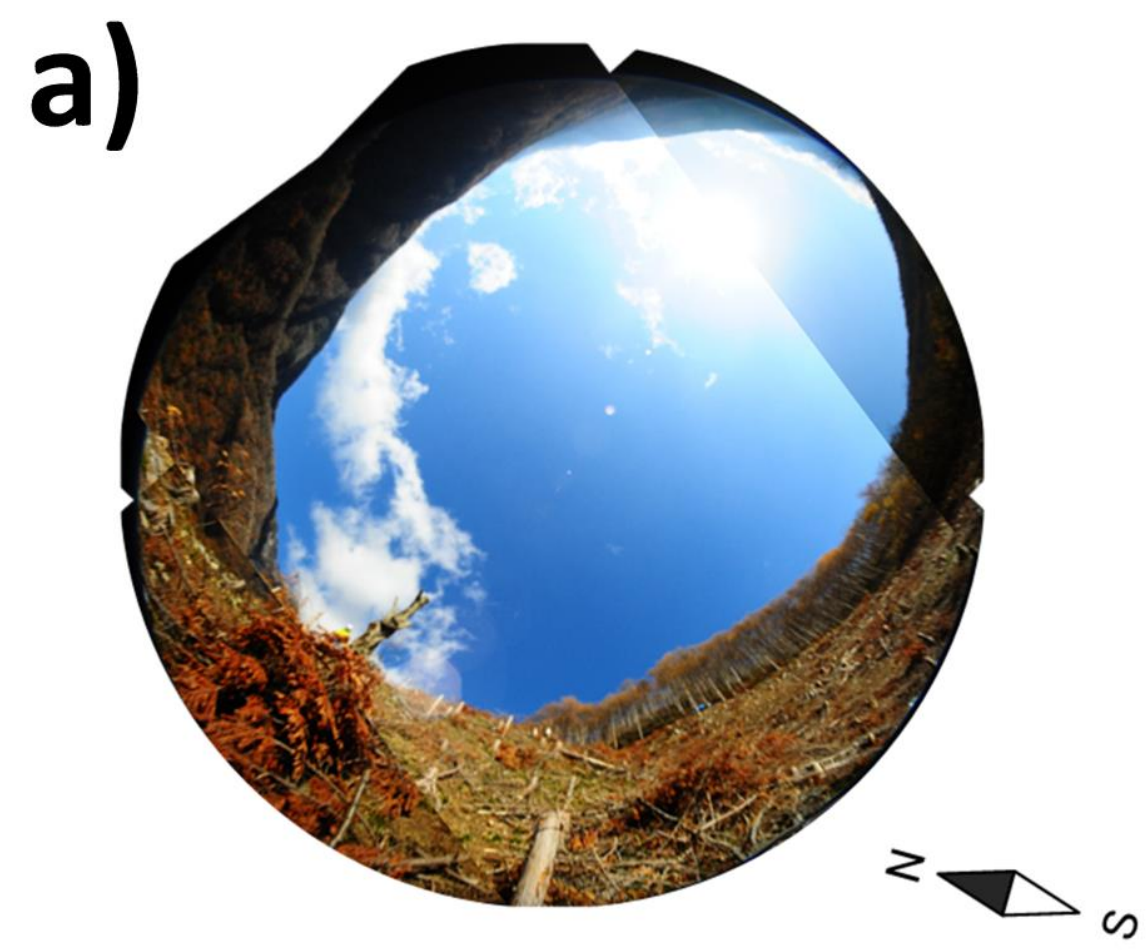

b)

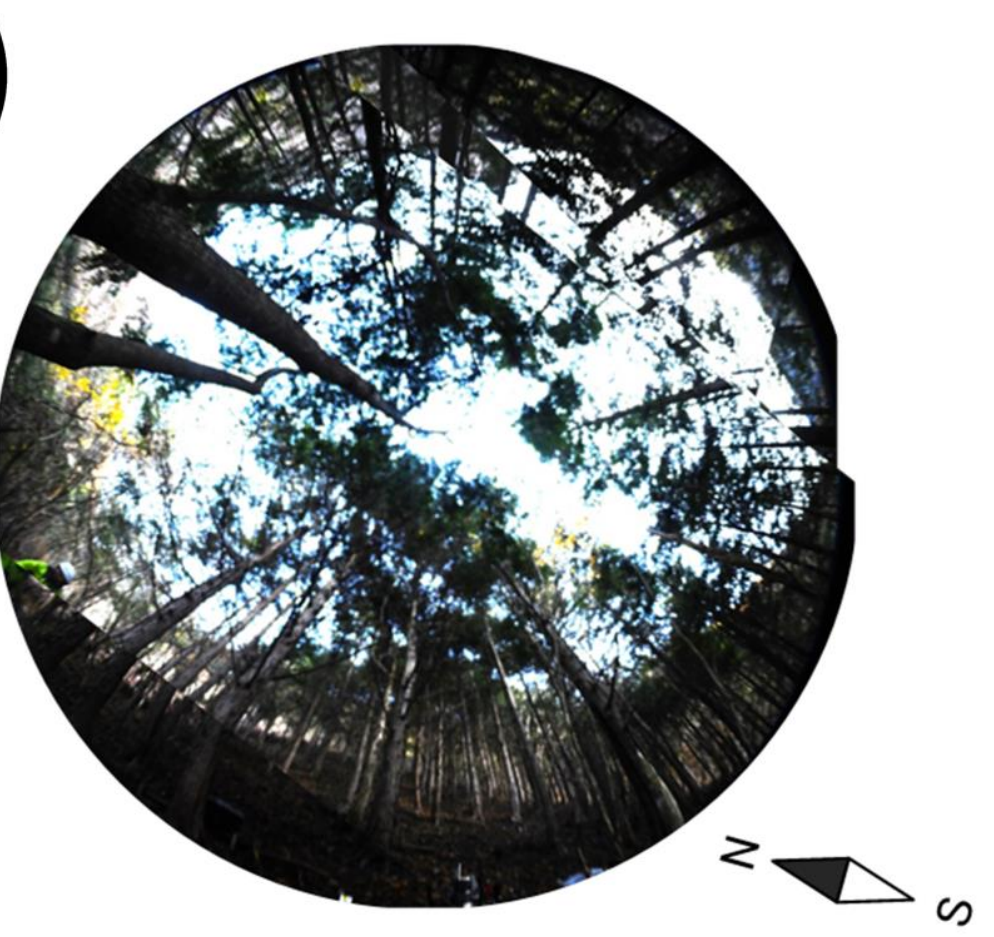

Fig. 4 

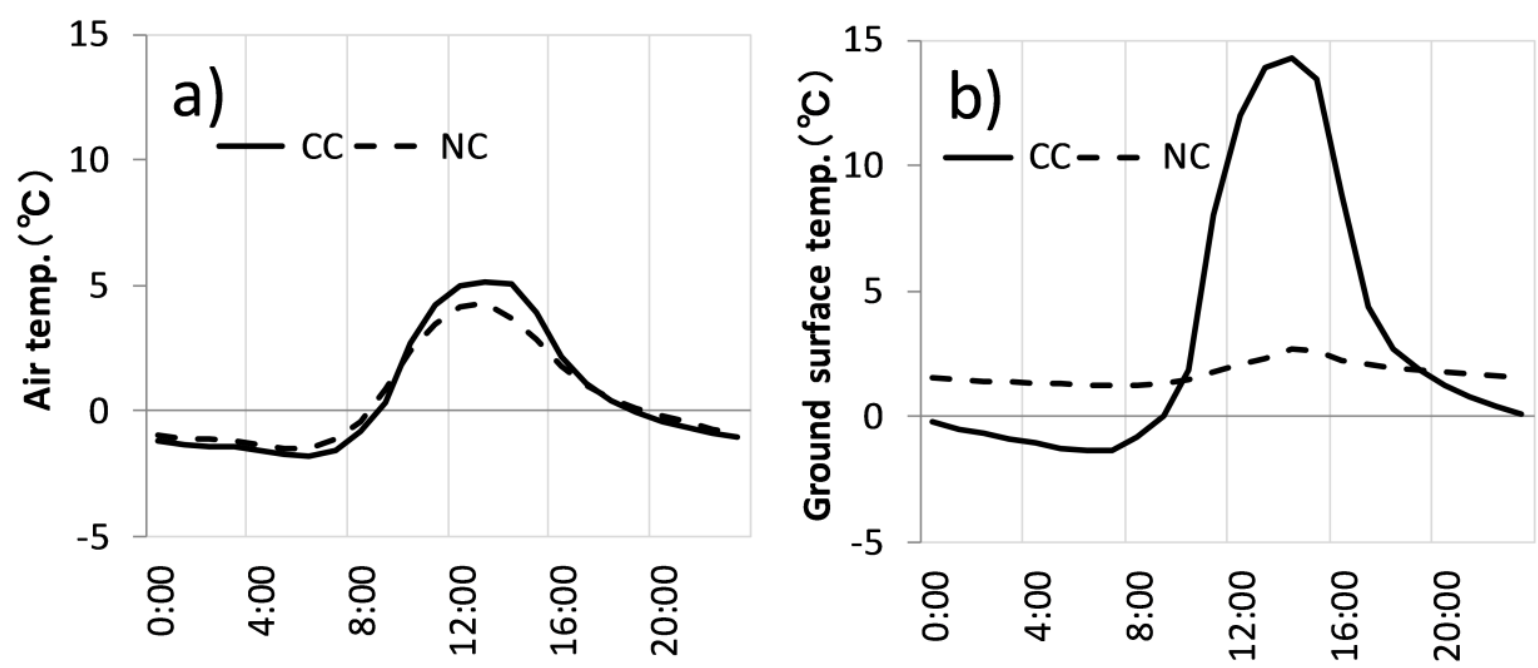

Fig. 5

a)

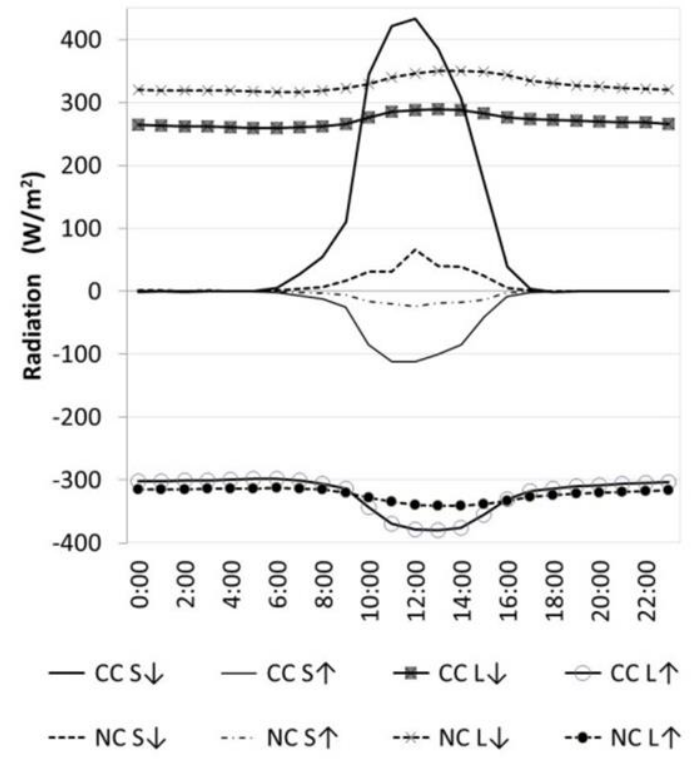

b )

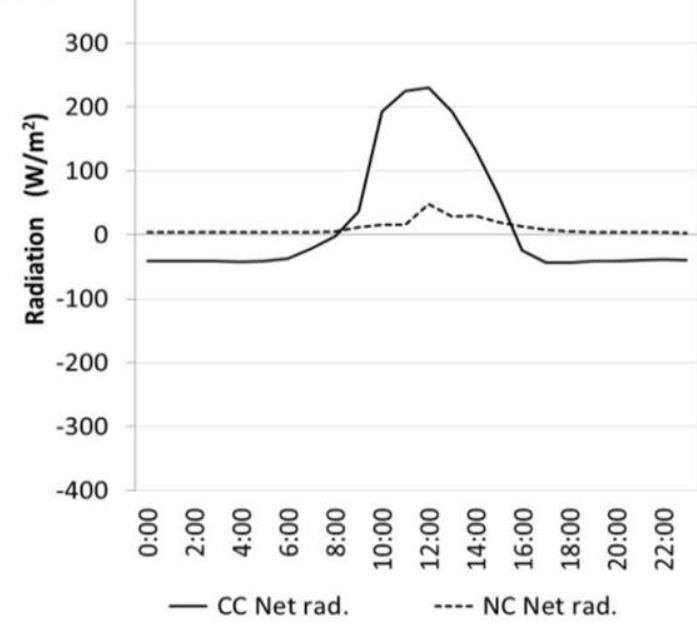

Fig. 6 


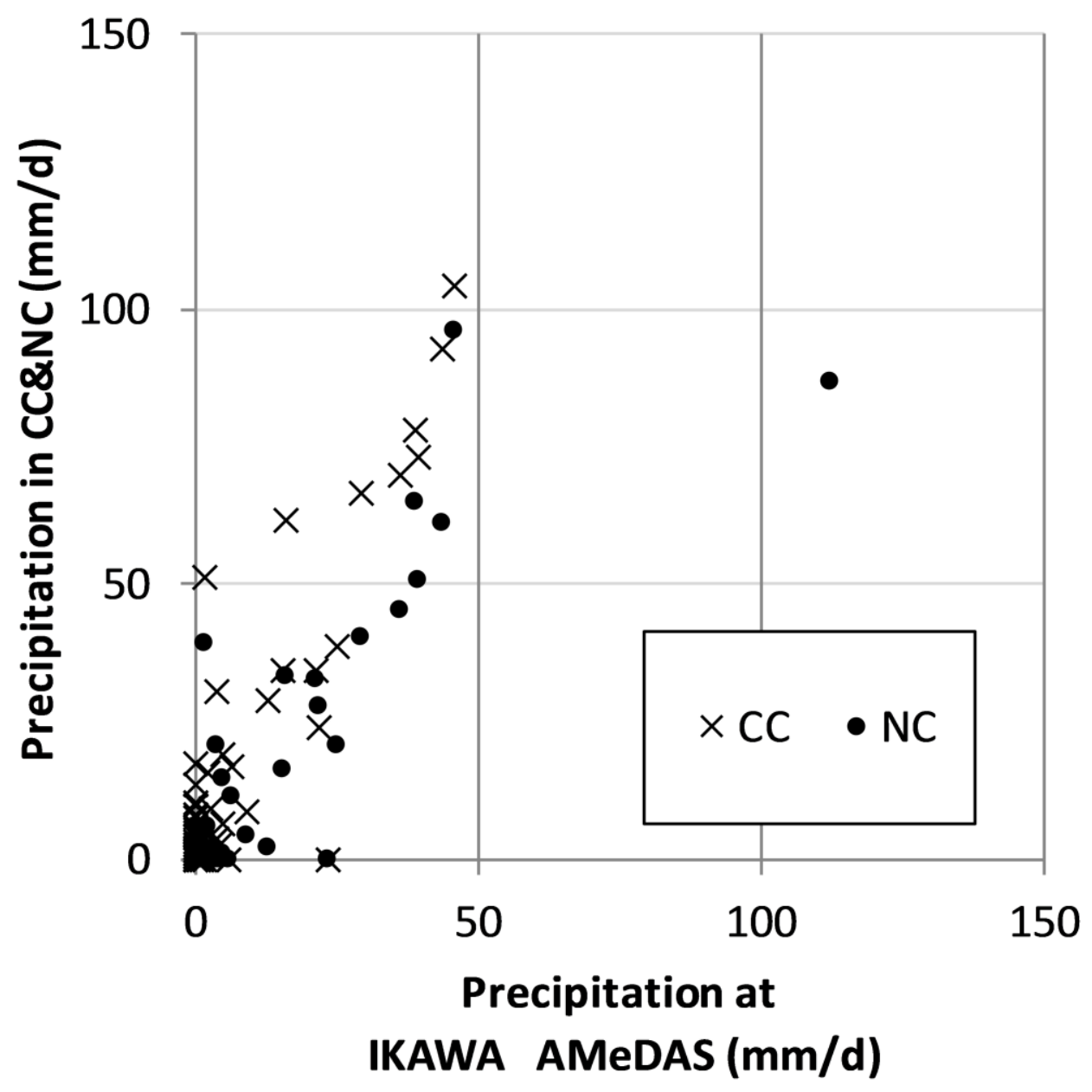

Fig. 7 

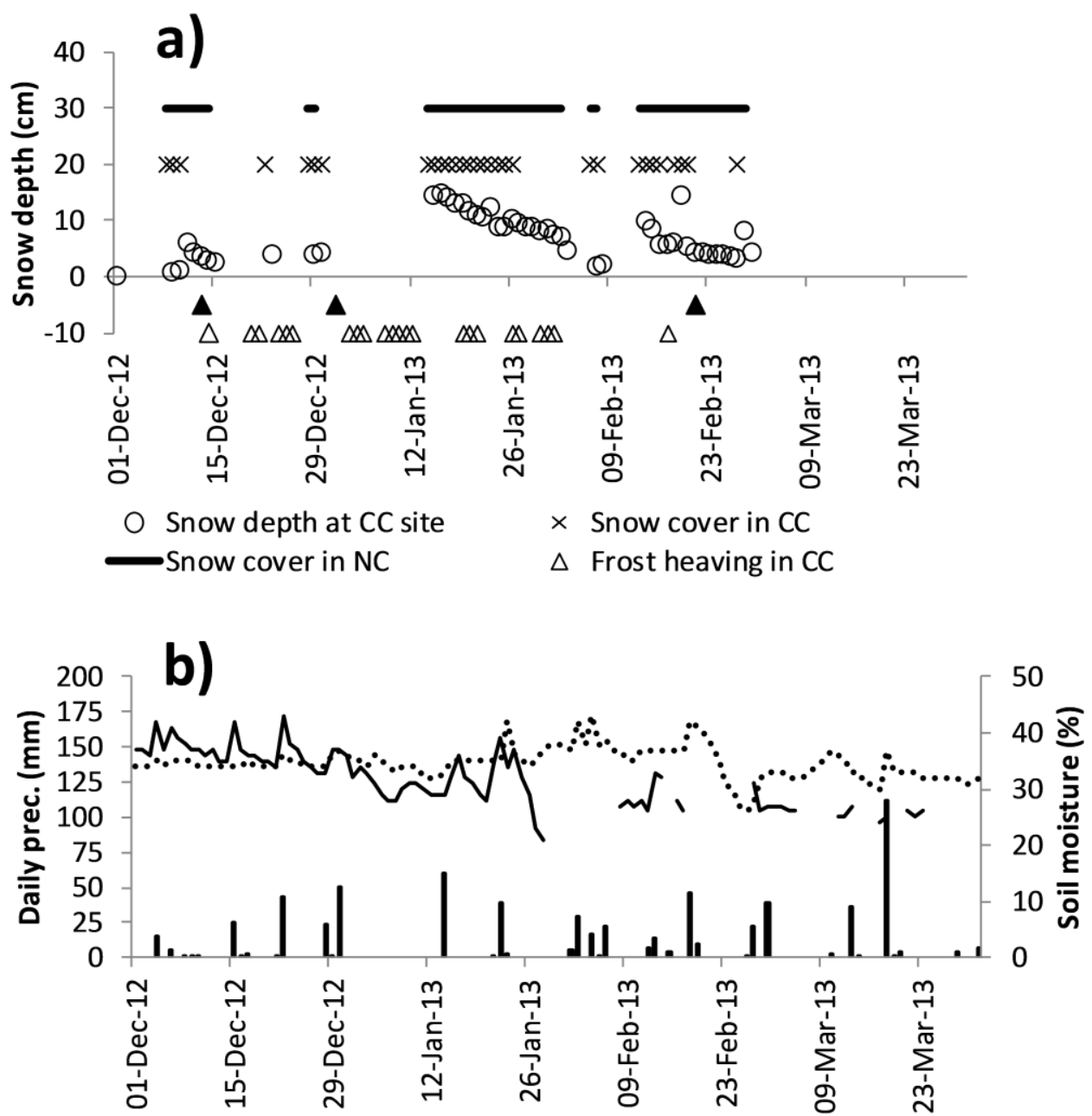

AMeDAS prec.

S.M. at NC site

- S.M. at CC site

Fig. 8
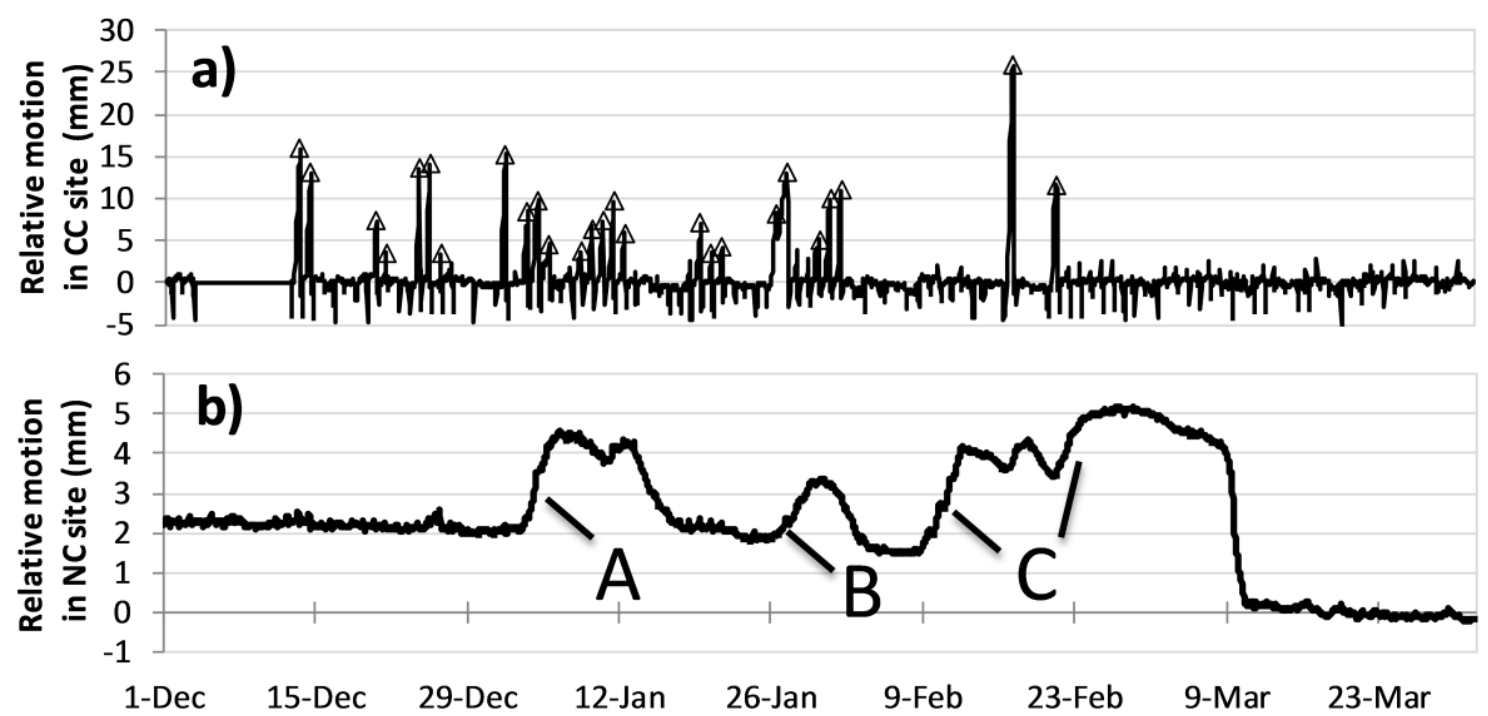

Fig. 9 


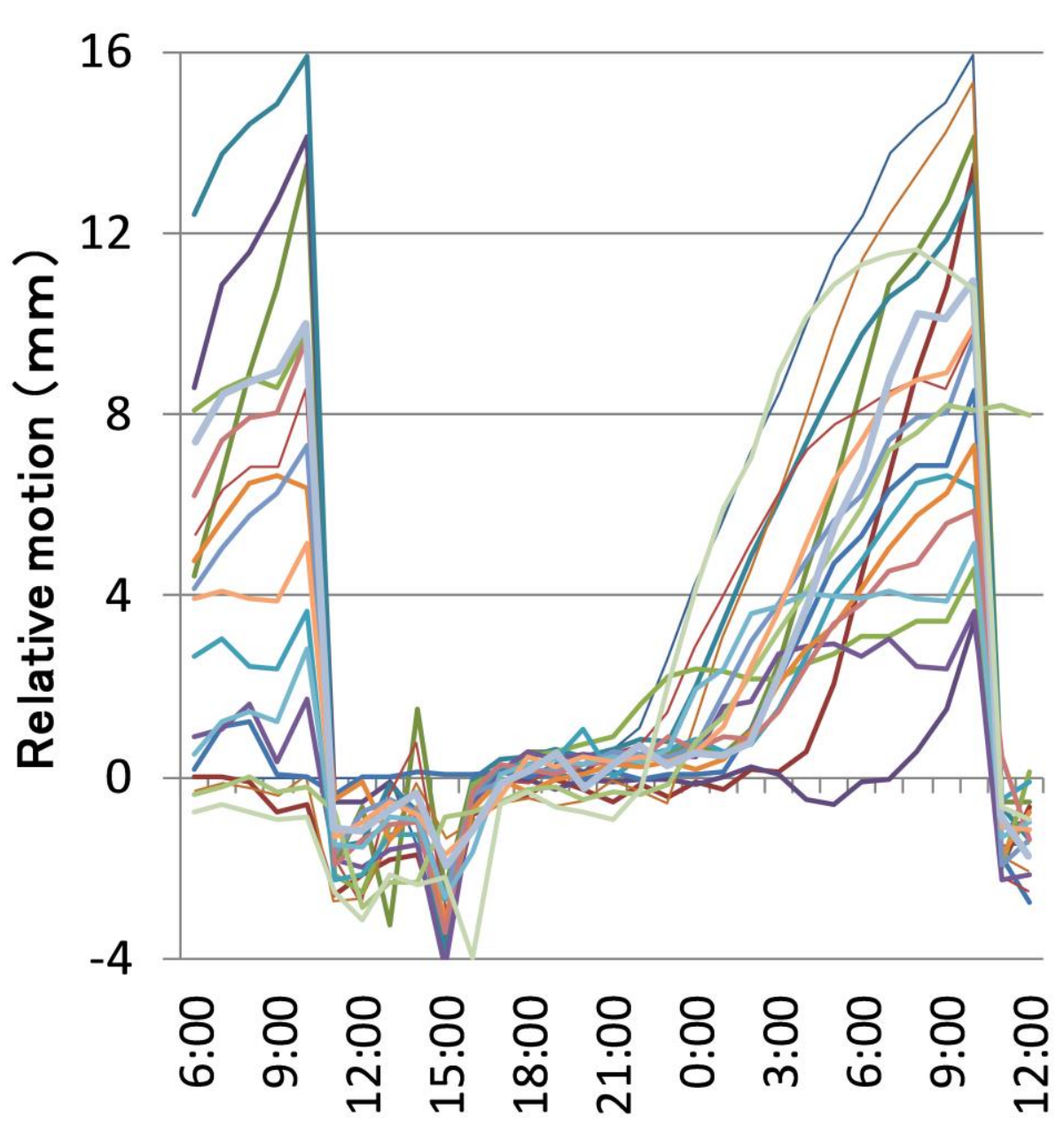

-13-Dec

- 24-Dec

- 25-Dec

- 26-Dec

-14-Dec

-1-Jan

-3-Jan

-4-Jan

- 5-Jan

- 8-Jan

-9-Jan

-10-Jan

-11-Jan

-12-Jan

- 26-Jan

-30-Jan

-31-Jan

-1-Feb 21-Feb

Fig. 10 


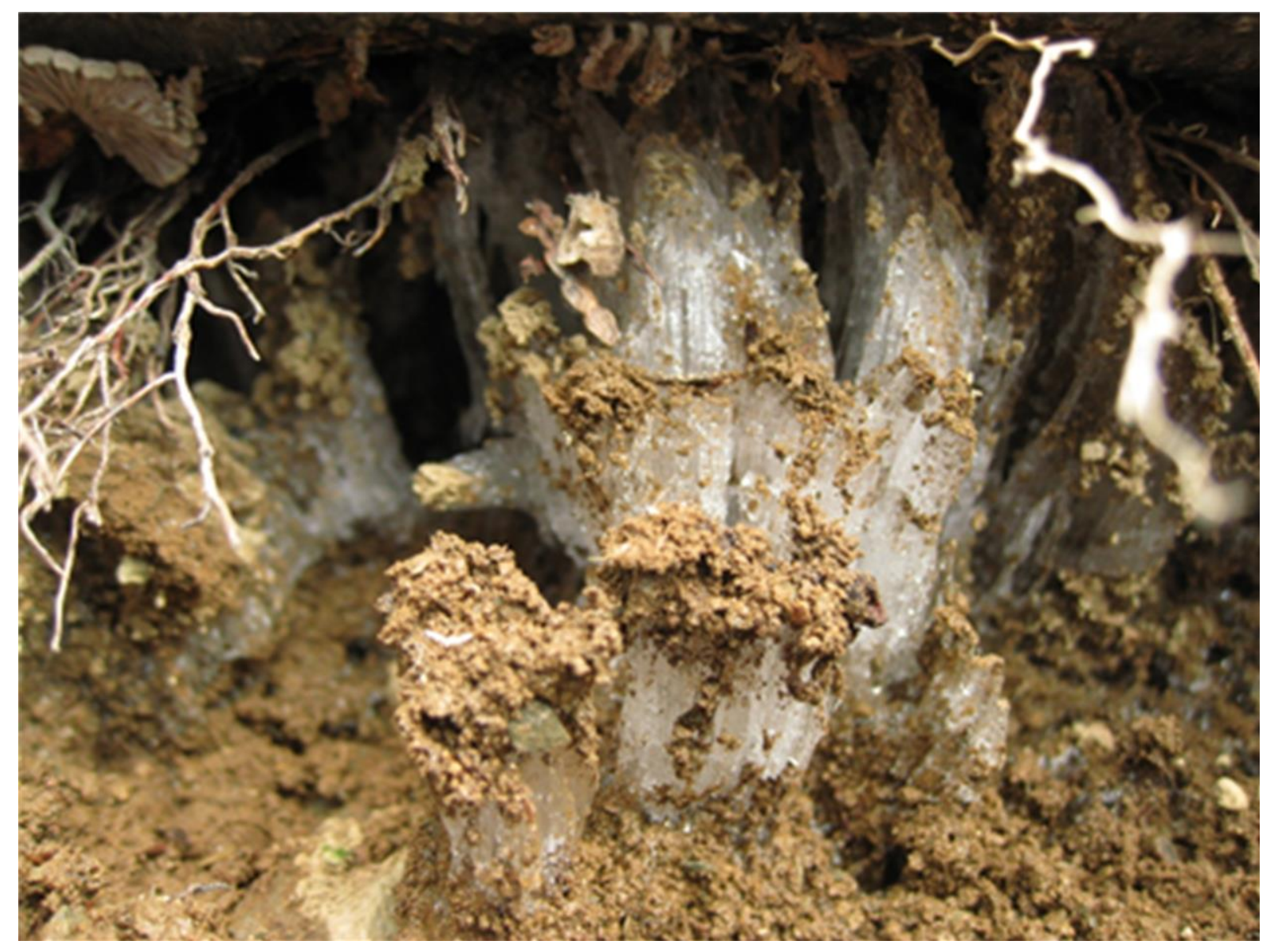

Fig. 11 
a) 16
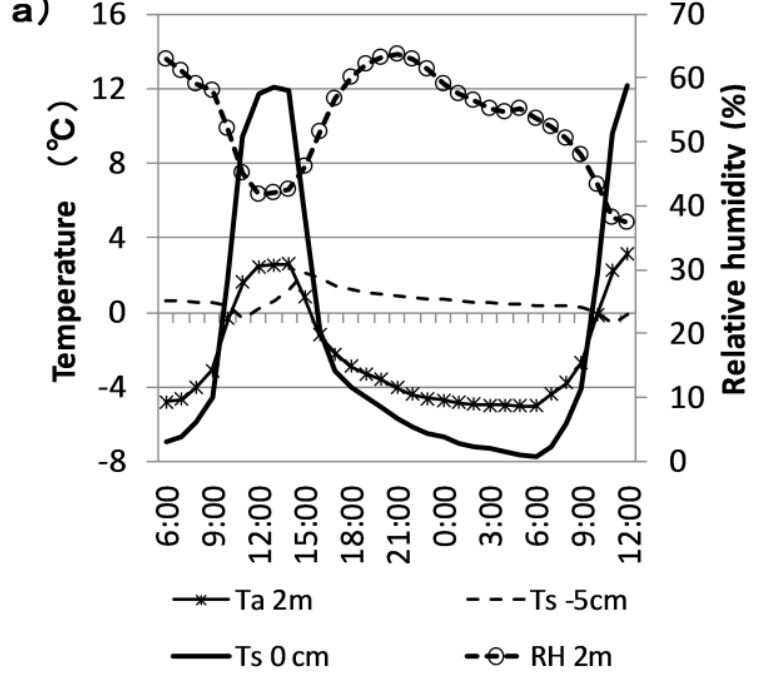

c)

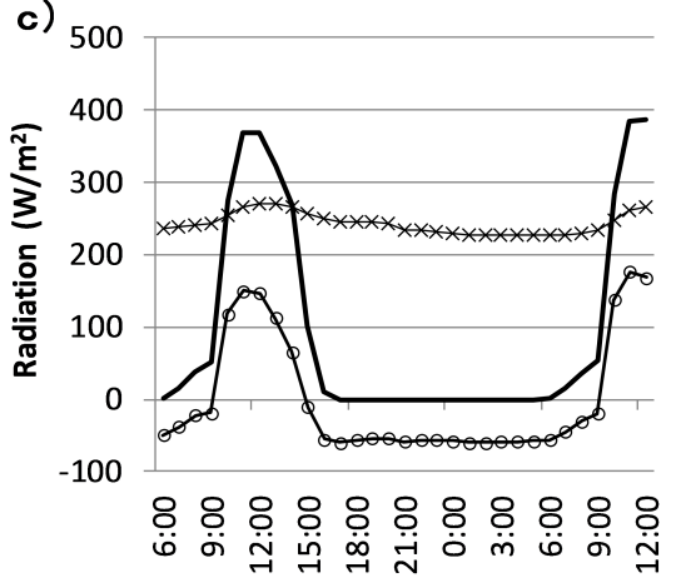

$\multimap S \downarrow \quad * L \downarrow \rightarrow R n$, b) 16

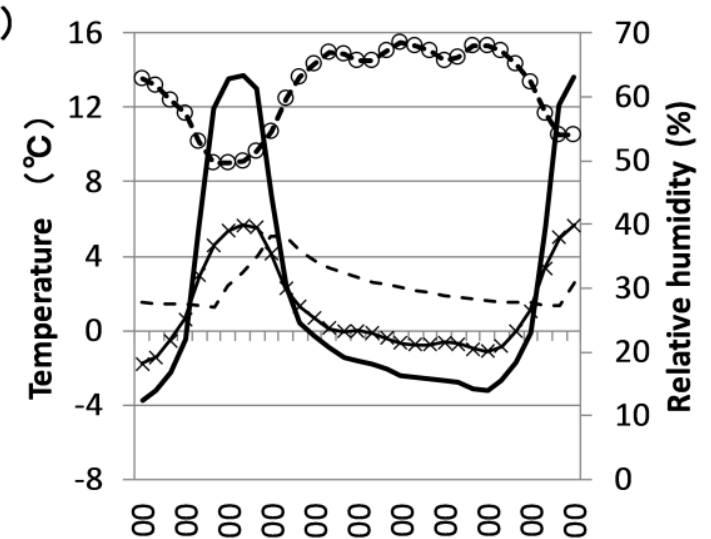

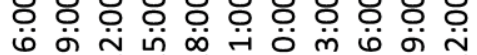

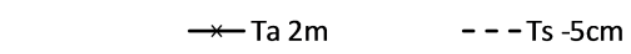

d) $500-\mathrm{Ts} 0 \mathrm{~cm} \quad-\ominus-\mathrm{RH} 2 \mathrm{~m}$

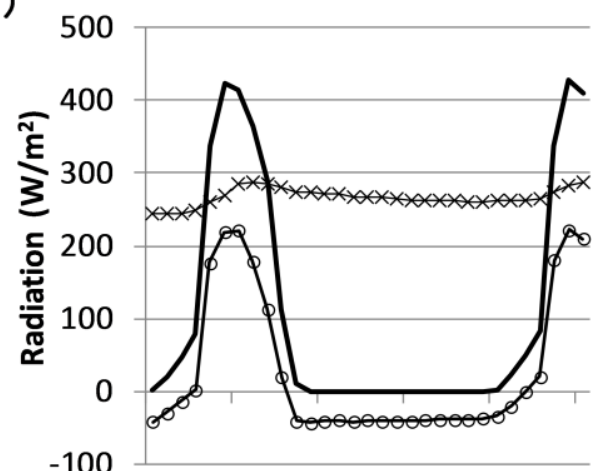

o o o o o o o o o o o o o o o o

— $\downarrow \quad *-\mathrm{L} \rightarrow \mathrm{Rn}$,

Fig. 12 


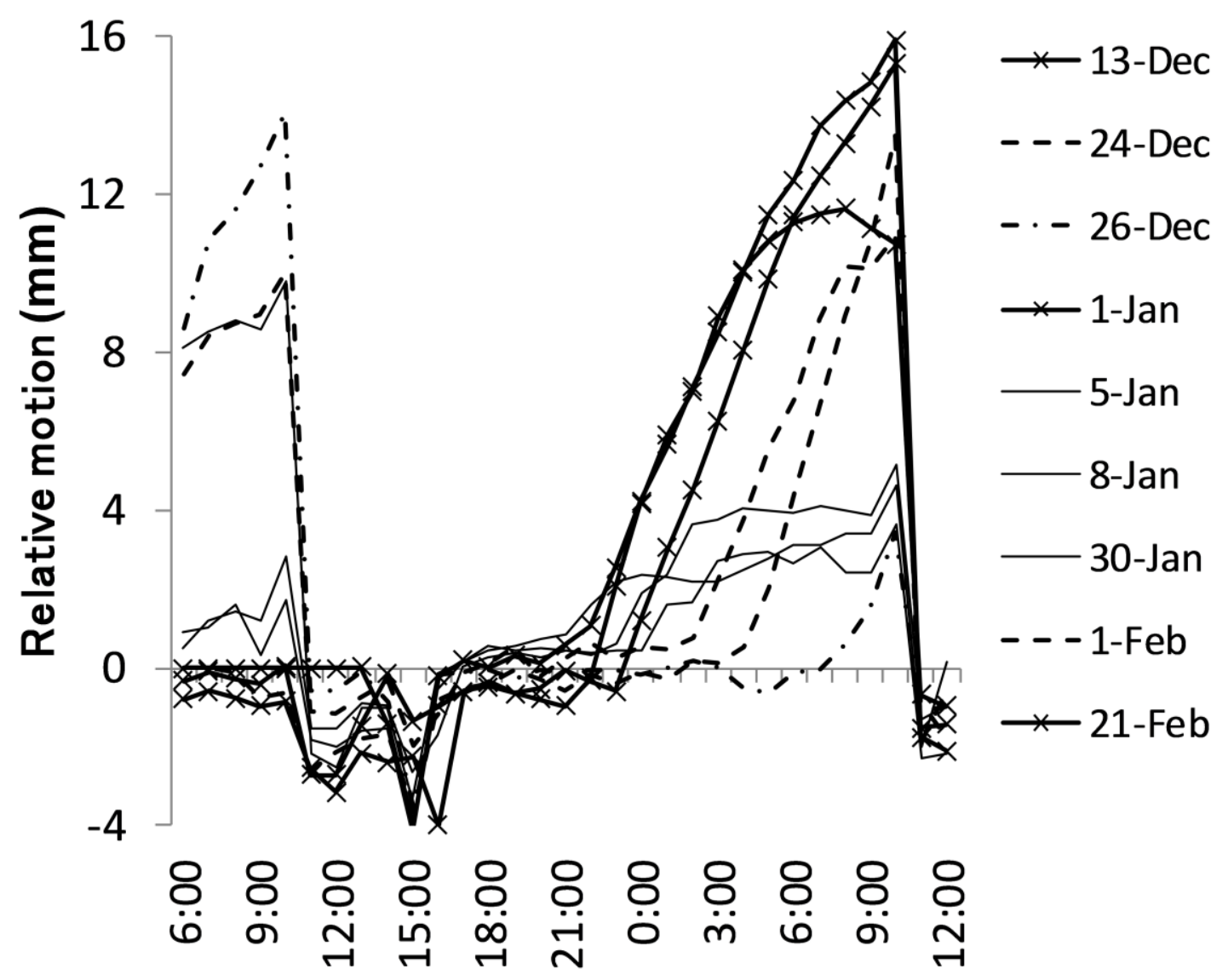

Fig. 13 


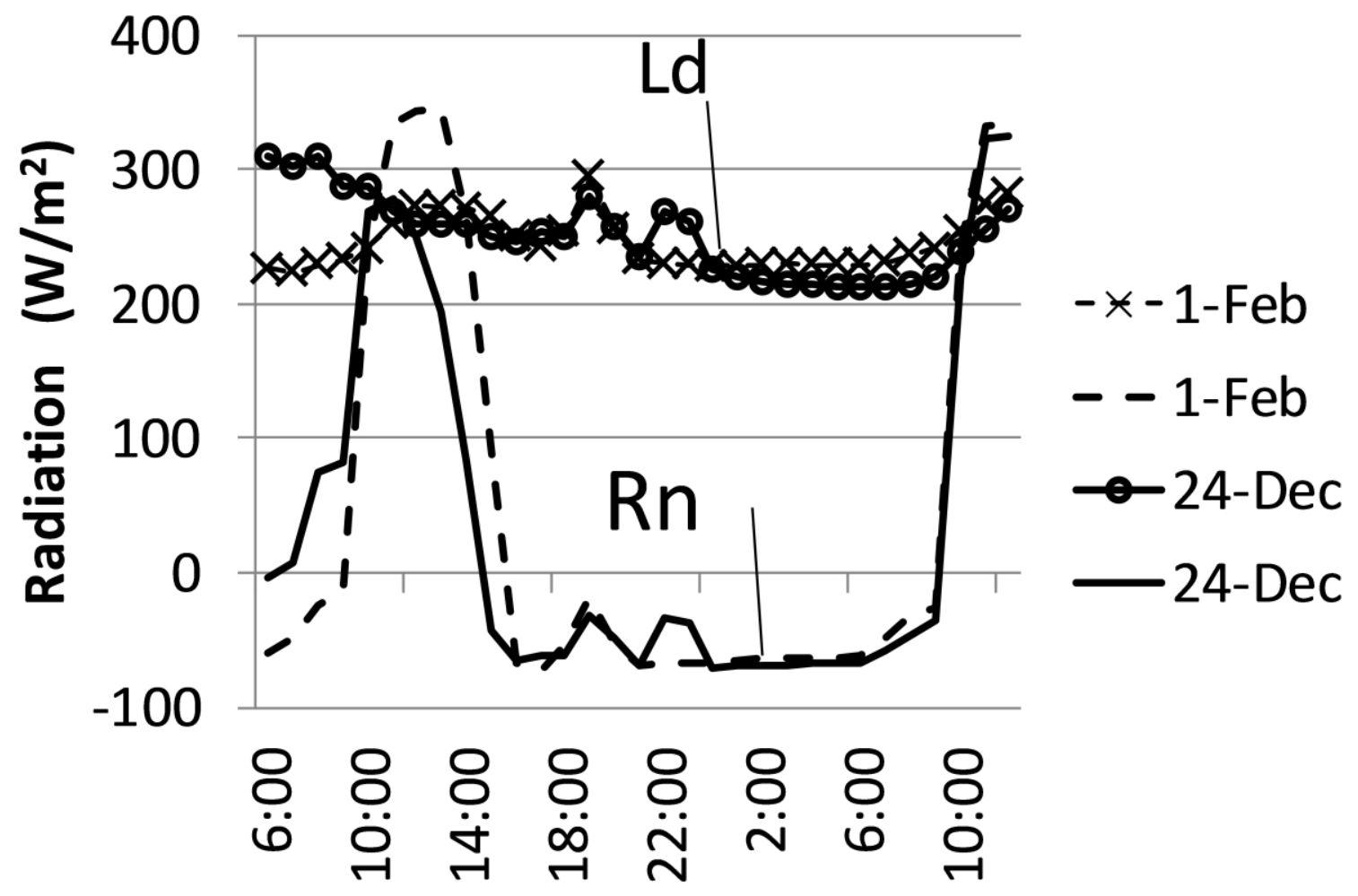

Fig. 14

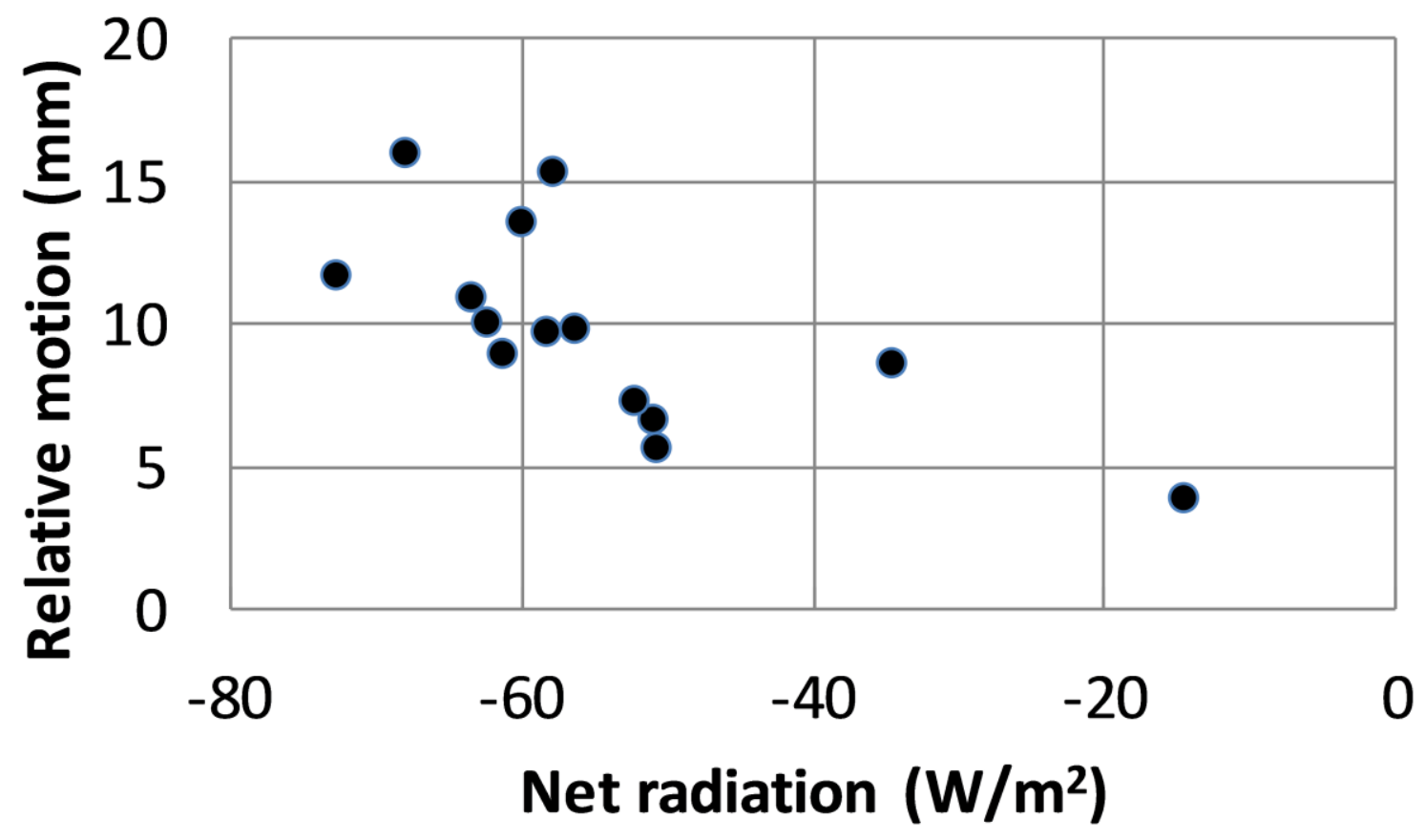

Fig. 15 


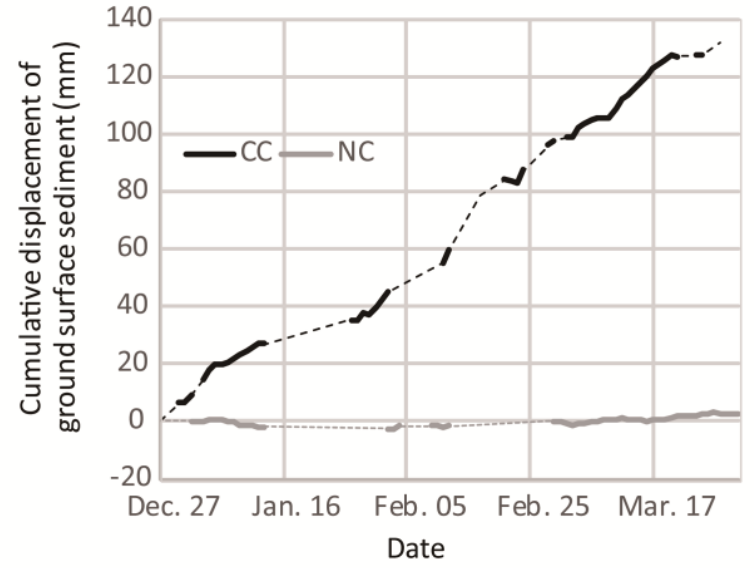

Fig. 16 